\title{
Rates of dinitrogen fixation and the abundance of diazotrophs in North American coastal waters between Cape Hatteras and Georges Bank
}

\author{
M. R. Mulholland, ${ }^{a},{ }^{*}$ P. W. Bernhardt, ${ }^{a}$ J. L. Blanco-Garcia, ${ }^{b}$ A. Mannino, ${ }^{c}$ K. Hyde, ${ }^{d}$ \\ E. Mondragon, ${ }^{\mathrm{e}, 1}$ K. Turk, ${ }^{\mathrm{e}}$ P. H. Moisander, ${ }^{\mathrm{e}, 2}$ and J. P. Zehre \\ a Old Dominion University, Department of Ocean, Earth and Atmospheric Sciences, Norfolk, Virginia \\ b Old Dominion University, Center for Coastal Physical Oceanography, Norfolk, Virginia \\ c National Aeronautics and Space Administration, Goddard Space Flight Center, Greenbelt, Maryland \\ dNational Oceanic and Atmospheric Administration, Northeast Fisheries Science Center, Narragansett, Rhode Island \\ e University of California Santa Cruz, Ocean Sciences Department, Santa Cruz, California
}

\begin{abstract}
We coupled dinitrogen $\left(\mathrm{N}_{2}\right)$ fixation rate estimates with molecular biological methods to determine the activity and abundance of diazotrophs in coastal waters along the temperate North American Mid-Atlantic continental shelf during multiple seasons and cruises. Volumetric rates of $\mathrm{N}_{2}$ fixation were as high as $49.8 \mathrm{nmol} \mathrm{N} \mathrm{L}-1 \mathrm{~d}^{-1}$ and areal rates as high as $837.9 \mu \mathrm{mol} \mathrm{N} \mathrm{m} \mathrm{N}^{-2} \mathrm{~d}^{-1}$ in our study area. Our results suggest that $\mathrm{N}_{2}$ fixation occurs at high rates in coastal shelf waters that were previously thought to be unimportant sites of $\mathrm{N}_{2}$ fixation and so were excluded from calculations of pelagic marine $\mathrm{N}_{2}$ fixation. Unicellular $\mathrm{N}_{2}$-fixing group A cyanobacteria were the most abundant diazotrophs in the Atlantic coastal waters and their abundance was comparable to, or higher than, that measured in oceanic regimes where they were discovered. High rates of $\mathrm{N}_{2}$ fixation and the high abundance of diazotrophs along the North American Mid-Atlantic continental shelf highlight the need to revise marine $\mathrm{N}$ budgets to include coastal $\mathrm{N}_{2}$ fixation. Integrating areal rates of $\mathrm{N}_{2}$ fixation over the continental shelf area between Cape Hatteras and Nova Scotia, the estimated $\mathrm{N}_{2}$ fixation in this temperate shelf system is about $0.02 \mathrm{Tmol} \mathrm{N} \mathrm{yr}^{-1}$, the amount previously calculated for the entire North Atlantic continental shelf. Additional studies should provide spatially, temporally, and seasonally resolved rate estimates from coastal systems to better constrain $\mathrm{N}$ inputs via $\mathrm{N}_{2}$ fixation from the neritic zone.
\end{abstract}

Dinitrogen $\left(\mathrm{N}_{2}\right)$ fixation supplies new nitrogen $(\mathrm{N})$ to the world's oceans, thereby alleviating $\mathrm{N}$ limitation of primary productivity; however, most prior measurements of pelagic marine $\mathrm{N}_{2}$ fixation rates are primarily from oligotrophic regions, where $\mathrm{N}$-depleted conditions are thought to favor growth of $\mathrm{N}_{2}$-fixing microorganisms (diazotrophs). Despite the recognition that biological $\mathrm{N}_{2}$ fixation ultimately controls the input term of the marine $\mathrm{N}$ budget and that diazotrophs contribute substantially to new production in oligotrophic gyres (Montoya et al. 2004; Capone et al. 2005; Zehr and Paerl 2008), little is known about the distribution of diazotrophs and their activity in most coastal regions, where $21-30 \%$ of the total oceanic primary productivity occurs (Jahnke 2010), and where geochemical and climatological models are poorly resolved (Gruber and Sarmiento 1997; Deutsch et al. 2007). Rates of oceanic $\mathrm{N}_{2}$ fixation have been primarily reported from oligotrophic tropical and subtropical regions where nutrients (primarily $\mathrm{N}$ ) are depleted and warm surface temperatures are thought to be favorable for $\mathrm{N}_{2}$ fixation, at least by Trichodesmium, the most commonly studied diazotroph (Carpenter and Capone 2008; Zehr and Paerl 2008). However, evidence now suggests that other groups of oceanic diazotrophic

\footnotetext{
*Corresponding author: mmulholl@odu.edu
}

Present addresses:

${ }^{1}$ North Coast Laboratories, Arcata, California

${ }^{2}$ Department of Biology, University of Massachusetts Dartmouth, North Dartmouth, Massachusetts cyanobacteria thrive across a broader range of environments than previously thought (Moisander et al. 2010) and therefore global rates of $\mathrm{N}_{2}$ fixation may be underestimated. Consistent with this observation, recent geochemical models hint that global marine $\mathrm{N}_{2}$ fixation has been underestimated by models and field sampling, and determining sources of this missing $\mathrm{N}$ may be an important step in resolving oceanic $\mathrm{N}$ budgets (Gruber and Sarmiento 1997; Codispoti 2006; Deutsch et al. 2007).

Previous reports suggest that planktonic $\mathrm{N}_{2}$ fixation is undetectable or insignificant in most estuarine and coastal waters, including those along the North American MidAtlantic shelf (Howarth et al. 1988; Zehr and Paerl 2008; Conley et al. 2009). However there are few rate measurements to support this assertion. The diversity of nifH, the gene encoding the iron protein in the enzyme nitrogenase that mediates $\mathrm{N}_{2}$ fixation, has been shown to be far greater in estuarine environments such as the Chesapeake Bay (Zehr et al. 2003; Jenkins et al. 2004; Short et al. 2004) than in oceanic environments (Zehr et al. 2003), which suggests that the genetic capability for $\mathrm{N}_{2}$ fixation may be greater in estuarine-influenced coastal systems. However, the high estuarine nifH diversity may also be due to contributions from organisms transported into these systems from sediments, soils, terrigenous material, and other allochthonous inputs, rather than to populations of autochthonous diazotrophs actively fixing $\mathrm{N}_{2}$ in these systems. Along the North American Mid-Atlantic shelf, inputs of microbes from several large estuaries, including the Chesapeake Bay, 
can be augmented by the introduction of tropical and subtropical diazotrophs that are advected into coastal waters from the Gulf Stream, where $\mathrm{N}_{2}$ fixers are known to be abundant (Capone et al. 2005; Carpenter and Capone 2008). Tropical marine $\mathrm{N}_{2}$ fixers commonly occur in Gulf Stream-influenced coastal waters south of Cape Hatteras (Prufert-Bebout et al. 1993).

Oligotrophic tropical and subtropical marine environments depleted in dissolved inorganic nitrogen (DIN = $\left.\left(\mathrm{NO}_{3}^{-}+\mathrm{NO}_{2}^{-}+\mathrm{NH}_{4}^{+}\right)\right)$, and eutrophic fresh and brackish water environments enriched in phosphorus $(\mathrm{P})$, have been thought to be primary sites for $\mathrm{N}_{2}$ fixation in aquatic systems (Howarth et al. 1988; Zehr and Paerl 2008; Conley et al. 2009). Consistent with this notion, expression of nifH genes has been previously observed primarily in oligotrophic waters, including the temperate and subtropical Pacific (Church et al. 2005; Needoba et al. 2007) and the subtropical and tropical Atlantic Ocean (Langlois et al. 2005). Despite the numerous sources of diazotrophic organisms to temperate coastal systems, planktonic $\mathrm{N}_{2}$ fixation has not been broadly examined in coastal marine systems because nutrient inputs in these systems can be high and this is thought to be a condition that is unfavorable for active $\mathrm{N}_{2}$ fixation (Nixon et al. 1996; Zehr et al. 2008; Conley et al. 2009). However, recent observations demonstrate that there is active $\mathrm{N}_{2}$ fixation in $\mathrm{NO}_{3}^{-}$-replete $\left(\sim 10 \mu \mathrm{mol} \mathrm{L}{ }^{-1}\right)$ waters below the upper mixed layer in the eastern tropical North Atlantic Ocean (5 stations; Voss et al. 2004), in surface waters in the English Channel (2 stations; Rees et al. 2009), and the Mekong River plume in the South China Sea (22 stations over 2 seasons; Grosse et al. 2010). In addition, diazotrophs and active $\mathrm{N}_{2}$ fixation have now been found at higher latitudes than was previously thought (Rees et al. 2009; Moisander et al. 2010). In this study, we further broaden the domain of active oceanic $\mathrm{N}_{2}$ fixation to include coastal ocean regions.

\section{Methods}

We measured $\mathrm{N}_{2}$ fixation rates and diazotroph abundance in coastal waters along the North American Mid-Atlantic continental shelf on oceanographic cruises between $36.5^{\circ} \mathrm{N}$ and $39^{\circ} \mathrm{N}$ and $-76^{\circ} \mathrm{W}$ to $-74^{\circ} \mathrm{W}$ aboard the R/V Hugh Sharp during summer and autumn 2006, and from Cape Hatteras to Georges Bank (between $35^{\circ} \mathrm{N}$ to $43^{\circ} \mathrm{N}$ and $-76^{\circ} \mathrm{W}$ to $-65^{\circ} \mathrm{W}$ ) during a cruise aboard the R/V Delaware II in August 2009. In order to understand the biogeographical and hydrographic constraints on the distribution of active $\mathrm{N}_{2}$ fixation and the diazotrophs mediating this process, we simultaneously measured nutrient concentrations and hydrographic parameters at stations distributed within our study area. Surface-water temperature and salinity mapping was also done using the ship's underway sampling system during the R/V Hugh Sharp cruises in 2006. In 2009, a weekly average of sea-surface temperature was constructed using Moderate Resolution Imaging Spectroradiometer Terra and Aqua satellite data.

At sampling stations, vertical profiles of temperature and salinity were measured using a conductivity, temperature, and depth sensor mounted to a sampling rosette. Water samples were collected at 2-4 depths using Niskin bottles mounted to the same rosette. Samples were collected from near-surface waters in the upper $6 \mathrm{~m}$ and from near the bottom (when the shallow-water column was well-mixed) or the fluorescence maximum at all stations. Additional water samples were collected between these depths or when features were identified during vertical profiling. Whole water was transferred directly to incubation bottles during 2006 and transferred to clean 10-liter carboys during 2009. In 2009, water from the carboys was then dispensed into incubation bottles. Samples destined for nutrient analyses were immediately filtered through 0.2$\mu \mathrm{m}$ Supor cartridge filters and filtrate was collected into sterile sample bottles and frozen. Frozen samples were transported to Old Dominion University (ODU) for analysis of DIN and dissolved inorganic phosphorus (DIP) as described below. Samples were also collected for analysis of chlorophyll $a(\mathrm{Chl} a)$. These samples were filtered onto glass-fiber (Whatman GF/F) filters $(0.7-\mu \mathrm{m}$ pore size) and frozen in sterile centrifuge tubes, transported to the laboratory at ODU and analyzed using the method of Welschmeyer (1994) within 2 weeks of sample collection during 2006 and within $18 \mathrm{~d}$ of sample collection during 2009.

Uptake experiments were initiated by adding tracer additions $(<10 \%)$ of highly enriched $(99 \%){ }^{15} \mathrm{~N}_{2}$ to gastight bottles filled with whole water (Montoya et al. 1996; Mulholland et al. 2006). We recognize that this method may underestimate $\mathrm{N}_{2}$ fixation during short incubations (Mohr et al. 2010); all of the data reported here are from experiments incubated for $24 \mathrm{~h}$ in on-deck incubators and so gas solubility was likely to be less problematic. If we allow for equilibration of the gas bubble over the first $8 \mathrm{~h}$ of the incubation period, we estimate that $\mathrm{N}_{2}$ fixation would be underestimated by a factor of about 1.4. Incubation bottles were placed in on-deck incubators equipped with flow-through seawater to maintain near-ambient temperatures. After $24 \mathrm{~h}$, incubations were terminated by filtration through precombusted $\left(450^{\circ} \mathrm{C}\right.$ for $\left.2 \mathrm{~h}\right) \mathrm{GF} / \mathrm{F}$ filters. Samples were placed into sterile microcentrifuge tubes, frozen, and transported to the laboratory for analysis. In the laboratory, samples were dried, pelletized into tin disks, and analyzed for total particulate $\mathrm{N}$ and carbon (C) and isotopic enrichment on a Europa 20-20 mass spectrometer equipped with an automated nitrogen and carbon analyzer preparation module. Rates of uptake were calculated using a mixing model (Montoya et al. 1996; Orcutt et al. 2001).

Areal rates of $\mathrm{N}_{2}$ fixation were calculated by integrating our rate measurements from the surface mixed layer and fluorescence maximum over the euphotic zone. This was defined as $1 \%$ of photosynthetic active radiation (PAR), and was determined directly using a PAR sensor mounted to the sampling rosette. To estimate integrated $\mathrm{N}_{2}$ fixation rates over the euphotic zone, we multiplied the average of rate measurements made in the surface mixed layer by its depth and the rate measurements made at the fluorescence maximum and below the surface mixed layer by the remainder of the euphotic depth, and then added the two together. The upper mixed layer depth was calculated 
using the Levitus sigma- $t$ criterion of 0.125 change from surface.

In the laboratory at ODU, frozen filtrate was thawed and nitrate plus nitrite and DIP concentrations were measured colorimetrically using an Astoria Pacific nutrient analyzer according to manufacturer specifications (Parsons et al. 1984). Detection limits were $0.02 \mu \mathrm{mol} \mathrm{L} \mathrm{L}^{-1}$ and $0.01 \mu \mathrm{mol} \mathrm{L}^{-1}$, respectively. Ammonium concentrations were measured manually using the phenol-hypochlorite method (Solarzano 1969), with a detection limit of $0.02 \mu \mathrm{mol} \mathrm{L}^{-1}$.

Samples for molecular analyses were collected onto precombusted $\left(450^{\circ} \mathrm{C}\right.$ for $\left.2 \mathrm{~h}\right) \mathrm{GF} / \mathrm{F}$ filters during 2006 (in duplicate from two depths-surface and chlorophyll fluorescence maximum) and using Sterivex filters $(0.2-\mu \mathrm{m}$ pore size) in 2009. Because of the larger pore size filters in 2006, some of the unicellular cyanobacteria smaller than $0.7 \mu \mathrm{m}$ may have passed through the filter, which caused an underestimate of nifH gene copies in some diazotrophic groups during that year. Samples were immediately frozen and stored in liquid nitrogen until transported to ODU, where they were transferred to $-80^{\circ} \mathrm{C}$ freezers. Samples were shipped overnight on dry ice to University of California at Santa Cruz, where deoxyribonucleic acid (DNA) extraction was carried out using a modified Qiagen Plant kit method (Moisander et al. 2008). Quantitative polymerase chain reaction (qPCR) was carried out using seven sets of Taqman ${ }^{\circledR}$ primer-probe sets (Church et al. 2005; Foster et al. 2007) in 2006 and three primer-probe sets in 2009, and previously published protocols (Short and Zehr 2005, 2007; Foster et al. 2007), to quantify the abundances of the major diazotroph groups in the study area. Diazotroph diversity was investigated by amplifying a partial nifH fragment using degenerate primers, and PCR products were cloned and sequenced (Zehr and Turner 2001). Sequences were trimmed and imported to an Arb database aligned using a profile Hidden Markov model (HMMER software) algorithm using a protein family (PFAM) seed alignment. The new translated sequences were aligned to the existing database using the FastAlign feature in Arb (Ludwig et al. 2004). A neighbor-joining tree was constructed with the amino-acid sequences. Bootstrapping was done using Mega 4.1 (Tamura et al. 2007). Unique sequences from each station were submitted to GenBank and their accession numbers are FJ756578FJ756722.

\section{Results}

During the July 2006 shelf cruise between the Chesapeake and Delaware Bay mouths, surface-water temperatures ranged from $21.0^{\circ} \mathrm{C}$ to $25.5^{\circ} \mathrm{C}$, surface salinity ranged from 22.9 to 34.7 , and surface $\mathrm{Chl} a$ concentrations ranged from $0.10 \mu \mathrm{g} \mathrm{L}^{-1}$ to $3.98 \mu \mathrm{g} \mathrm{L}^{-1}$ (Table 1). The highest Chl $a$ concentrations (1.88-3.98 $\left.\mu \mathrm{g} \mathrm{L}^{-1}\right)$ and lowest salinities (22.9-26.5) were observed in the Chesapeake Bay Plume (CBP)-influenced region. At shelf stations and those influenced by the Gulf Stream, surface Chl $a$ concentrations were lower $\left(0.10-0.42 \mu \mathrm{g} \mathrm{L}^{-1}\right)$ and salinity was higher (31.0-34.3). Surface DIN and DIP concentrations were

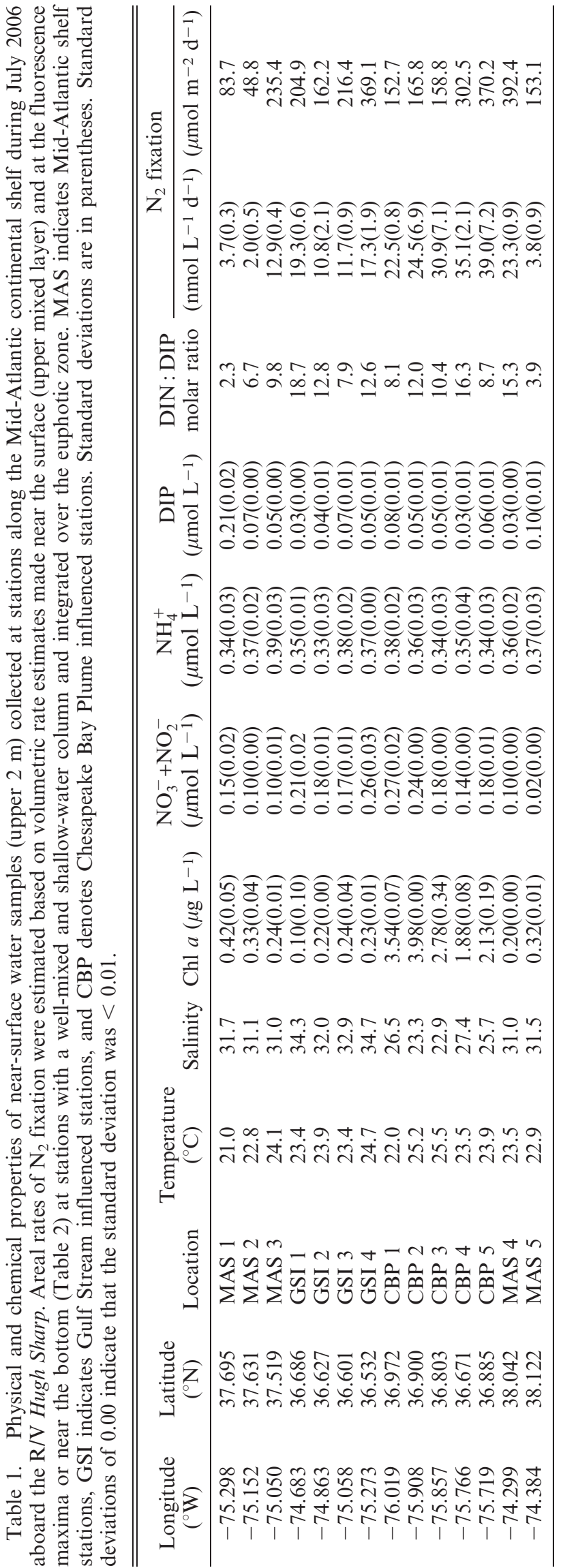




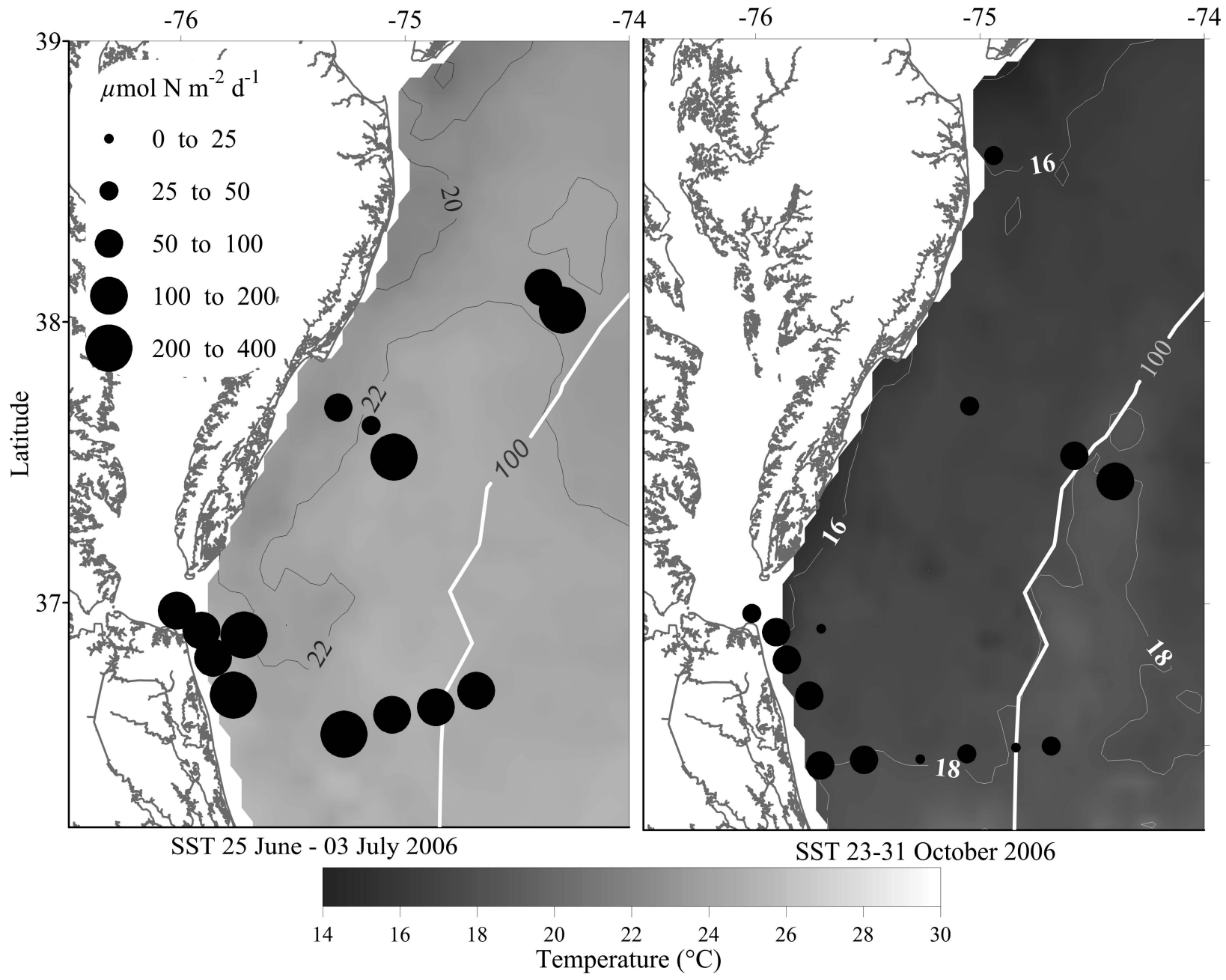

Fig. 1. Areal rates of $\mathrm{N}_{2}$ fixation ( $\mu \mathrm{mol} \mathrm{N} \mathrm{m} \mathrm{m}^{-2} \mathrm{~d}^{-1}$ ) in surface waters collected from the Mid-Atlantic shelf waters between Chesapeake and Delaware bays during cruises in (A) July and (B) October-November during 2006, superimposed upon the sea surface temperature (SST) fields observed during the respective field campaigns.

uniform across the study area during July 2006, ranging

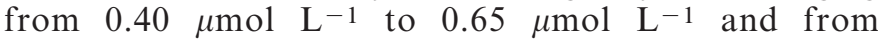
$0.03 \mu \mathrm{mol} \mathrm{L}-1$ to $0.21 \mu \mathrm{mol} \mathrm{L}-1$, respectively (Table 1 ). The DIN:DIP ratio ranged from 2.3 to 18.7 and was generally $<16$, indicative of $\mathrm{N}$ limitation. Average surface $\mathrm{N}_{2}$ fixation rates ranged from 2.0 to $39.0 \mathrm{nmol} \mathrm{L}^{-1} \mathrm{~d}^{-1}$ and depth integrated $\mathrm{N}_{2}$ fixation rates ranged from $48.8 \mu \mathrm{mol} \mathrm{m}^{-2} \mathrm{~d}^{-1}$ to $392.4 \mu \mathrm{mol} \mathrm{m}^{-2} \mathrm{~d}^{-1}$ over the study area (Table 1; Fig. 1A).

During the same cruise in July 2006, but in samples collected from the fluorescence maximum or near the bottom when the water column was shallow and wellmixed, water temperatures were lower (ranging from $11.0^{\circ} \mathrm{C}$ to $21.9^{\circ} \mathrm{C}$ ), salinity was higher (ranging from 29.4 to 35.4), and Chl $a$ concentrations were higher (ranging from $0.33 \mu \mathrm{g} \mathrm{L}^{-1}$ to $4.20 \mu \mathrm{g} \mathrm{L}^{-1}$ ) at all but the CBPinfluenced stations (Table 2). DIN concentrations were uniform, ranging from 0.46 to $0.64 \mu \mathrm{mol} \mathrm{N} \mathrm{L}{ }^{-1}$ at water depths $<40 \mathrm{~m}$. Higher $\mathrm{NO}_{3}^{-}+\mathrm{NO}_{2}^{-}$concentrations were observed at the two stations where samples were collected from $>40 \mathrm{~m}$. DIP concentrations ranged from $0.01 \mu \mathrm{mol} \mathrm{P}$ $\mathrm{L}^{-1}$ to $0.36 \mu \mathrm{mol} \mathrm{P} \mathrm{L} \mathrm{L}^{-1}$ in samples collected from the fluorescence maximum. DIN : DIP ratios were $<16$ at all but 2 stations, one where DIP was near the limit of analytical detection $\left(0.01 \mu \mathrm{mol} \mathrm{P} \mathrm{L}^{-1}\right)$ and the other at a deep station where there were high concentrations of $\mathrm{NO}_{3}^{-}$ $+\mathrm{NO}_{2}^{-}$. Volumetric rates of $\mathrm{N}_{2}$ fixation were lower in samples from the fluorescence maximum than in surfacewater samples, with average rates ranging from $1.0 \mathrm{nmol} \mathrm{L}-1 \mathrm{~d}^{-1}$ to $8.8 \mathrm{nmol} \mathrm{L}^{-1} \mathrm{~d}^{-1}$. When we compared $\mathrm{N}_{2}$ fixation rates and temperature, we observed higher $\mathrm{N}_{2}$ fixation rates at higher temperatures (Fig. 2A). However, the water column was stratified during this period, and so all of the samples with water temperatures $<20^{\circ} \mathrm{C}$ were collected at the fluorescence maximum, where light levels were also lower.

During the October-November 2006 cruise, surfacewater temperatures were lower than in July, ranging from $15.2^{\circ} \mathrm{C}$ to $21.6^{\circ} \mathrm{C}$ (Table 3 ). However, surface salinity and Chl $a$ concentrations were similar to those measured in July, ranging from $23.5 \mu \mathrm{g} \mathrm{Chl} a \mathrm{~L}^{-1}$ to $34.6 \mu \mathrm{g} \mathrm{Chl} a \mathrm{~L}^{-1}$ and from $0.46 \mu \mathrm{g} \mathrm{Chl} a \mathrm{~L}^{-1}$ to $5.88 \mu \mathrm{g} \mathrm{Chl} a \mathrm{~L}^{-1}$, respectively. Higher concentrations of Chl $a$ were observed at shelf stations in November compared with July. DIN 


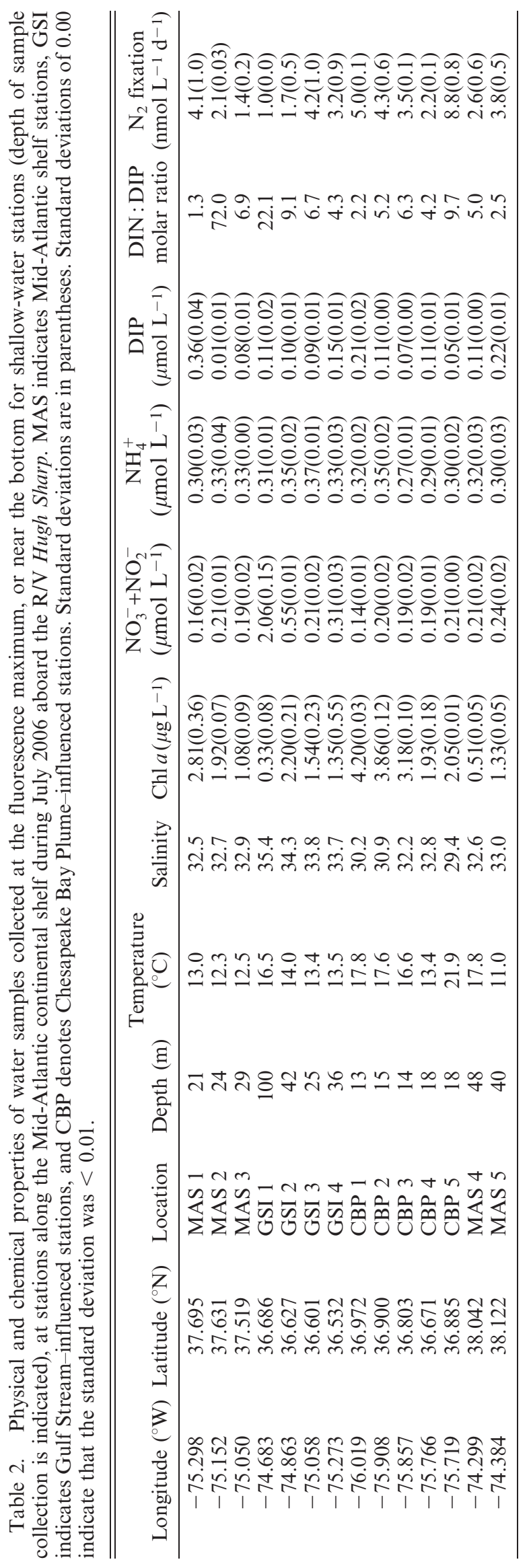

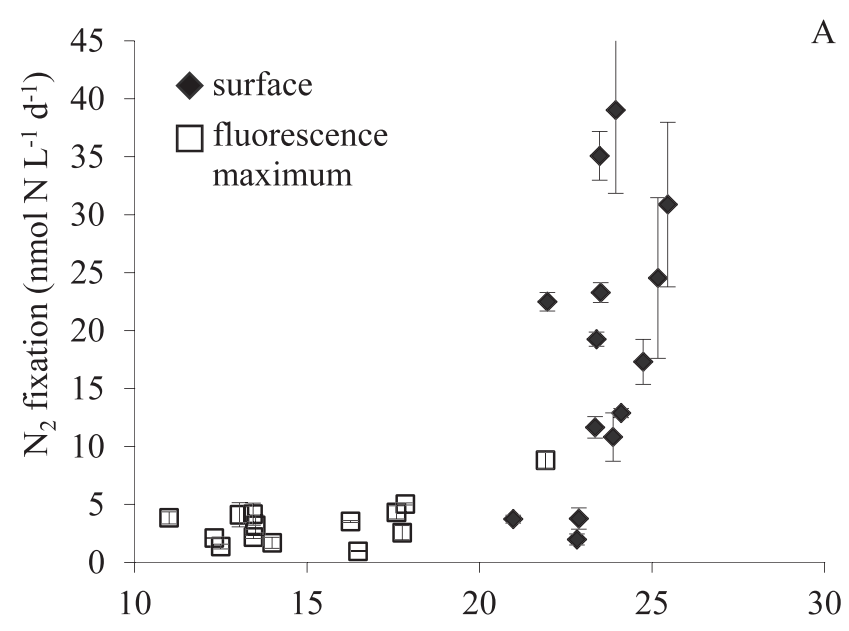
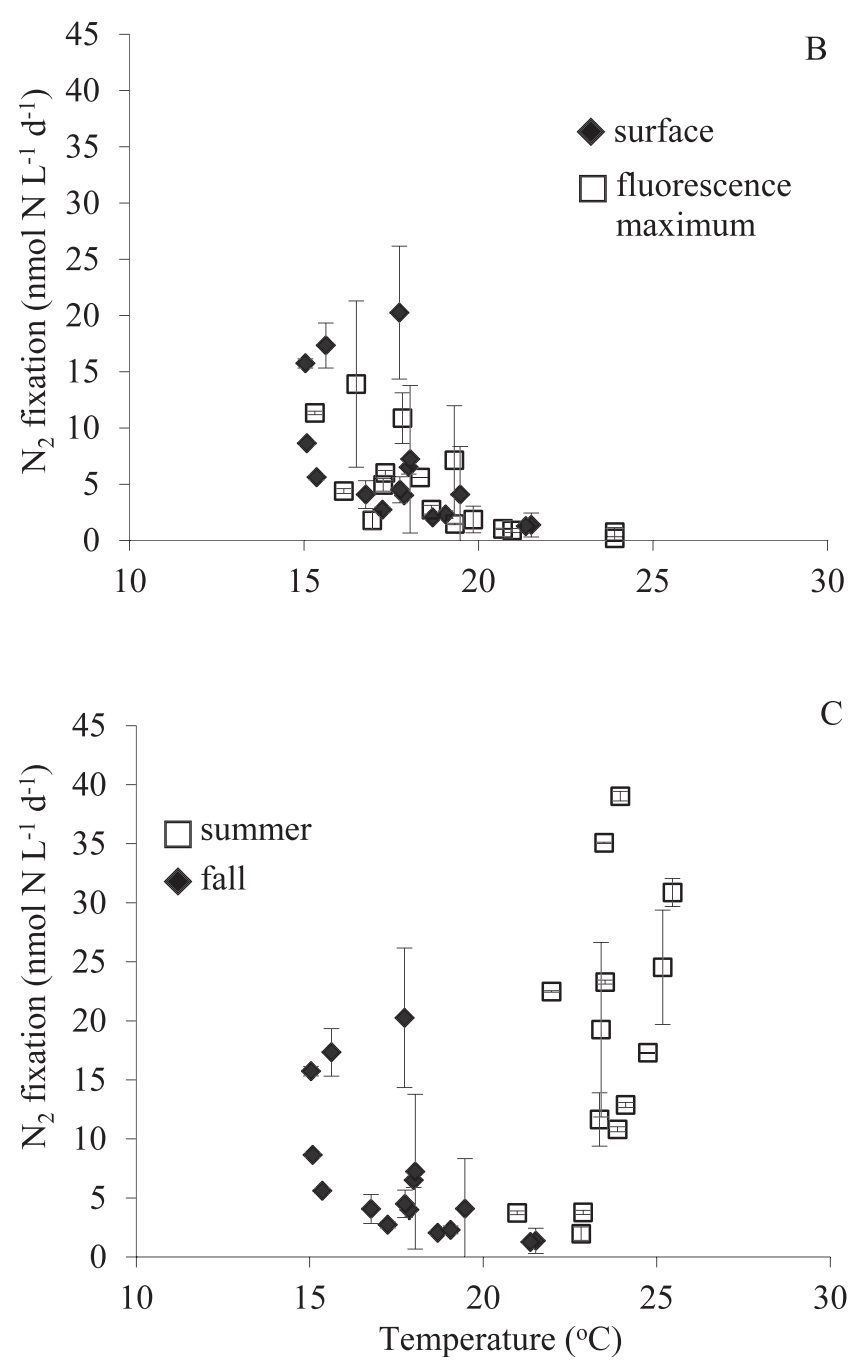

Fig. 2. Relationship between volumetric rates of $\mathrm{N}_{2}$ fixation (nmol L $\mathrm{L}^{-1} \mathrm{~d}^{-1}$ ) and temperature in samples collected from near the surface and at the fluorescence maximum during cruises in (A) July and (B) October-November during 2006, and in (C) surfacewater samples pooled over the summer (July) and autumn (OctNov) cruises. 


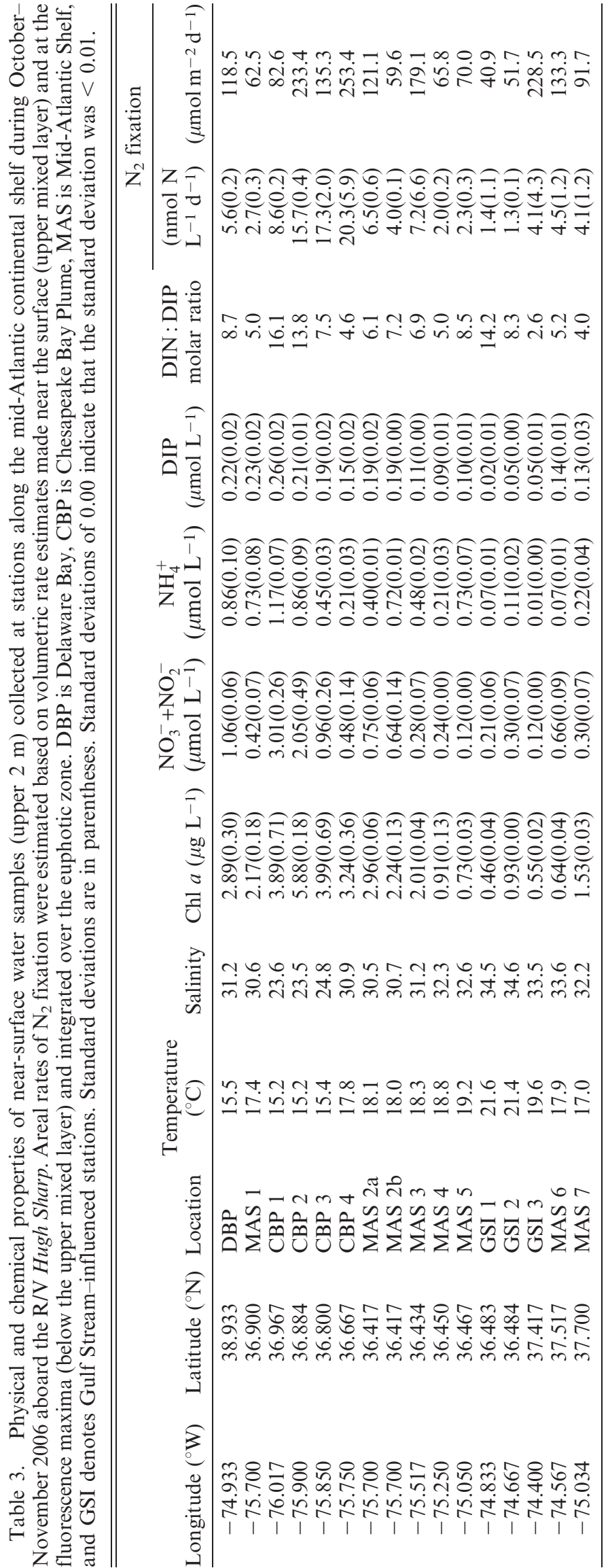

and DIP concentrations in surface waters were higher than those observed in July, ranging from $0.13 \mu \mathrm{mol} \mathrm{L}^{-1}$ to 4.18 and from $0.02 \mu \mathrm{mol} \mathrm{L}^{-1}$ to $0.26 \mu \mathrm{mol} \mathrm{L}^{-1}$, respectively. The highest nutrient concentrations were observed at plumeinfluenced stations. DIN : DIP ratios were generally $\leq 16$ in surface waters (Table 3 ). Average volumetric $\mathrm{N}_{2}$ fixation rates in surface waters ranged from $1.3 \mathrm{nmol} \mathrm{L}^{-1} \mathrm{~d}^{-1}$ to $20.3 \mathrm{nmol} \mathrm{L}^{-1} \mathrm{~d}^{-1}$ during November, lower than the range observed during summer. Depth-integrated $\mathrm{N}_{2}$ fixation rates ranged from 40.9 to $253.4 \mu \mathrm{mol} \mathrm{m}^{-2} \mathrm{~d}^{-1}$ during this time period (Table 3; Fig. 1B).

Because the water column was well-mixed during October-November 2006, temperature and salinity were similar in surface and deeper water samples (Tables 3 and 4). Nutrient concentrations and DIN:DIP ratios were also similar at both depths, and DIN:DIP ratios were usually $\leq 16$. On average, volumetric rates of $\mathrm{N}_{2}$ fixation were lower at the fluorescence maximum (range of 0.2 $13.9 \mathrm{nmol} \mathrm{N} \mathrm{L} \mathrm{N}^{-1} \mathrm{~d}^{-1}$ ) than in surface waters. However, during the autumn cruise, rates of $\mathrm{N}_{2}$ fixation in samples collected from the fluorescence maximum or near the bottom at plume-influenced stations were higher than those observed during the summer cruise. When we compared $\mathrm{N}_{2}$ fixation rates and temperature for the autumn cruise, we observed higher $\mathrm{N}_{2}$ fixation rates at lower temperatures and no distinct grouping of samples from the surface and the fluorescence maximum (Fig. 2B), likely because the water column was well-mixed during this period, and temperatures were similar in samples collected at the surface and the fluorescence maximum. Pooling data from surface-water samples from the summer and autumn cruises, we observed higher rates of $\mathrm{N}_{2}$ fixation at higher temperatures but also lower $\mathrm{N}_{2}$ fixation rates during autumn when light intensity was lower than during the July cruise (Fig. 2C).

During the geographically more extensive cruise during August 2009, there was a wider range of surface-water temperatures over the study area; from $11.4^{\circ} \mathrm{C}$ to $23.1^{\circ} \mathrm{C}$ for samples collected on Georges Bank and in the Gulf of Maine, and from $21.0^{\circ} \mathrm{C}$ to $27.0^{\circ} \mathrm{C}$ along the Mid-Atlantic shelf between $35.745^{\circ} \mathrm{N}$ and $41.314^{\circ} \mathrm{N}$ latitude (Table 5). Surface salinities ranged from 29.9 to 33.0 , and $\mathrm{Chl} a$ concentrations ranged from $0.12 \mu \mathrm{g} \mathrm{L}^{-1}$ to $4.54 \mu \mathrm{g} \mathrm{L}^{-1}$, DIN concentrations ranged from below the limit of analytical detection to $5.90 \mu \mathrm{mol} \mathrm{N} \mathrm{L}^{-1}$, and DIP concentrations ranged from the limit of analytical detection to $1.02 \mu \mathrm{mol} \mathrm{P} \mathrm{L}-1$ during July 2009 . On average, DIN and DIP concentrations were more than double at the Georges Bank and Gulf of Maine stations $\left(2.46 \mu \mathrm{mol} \mathrm{L}^{-1}\right.$ and $0.51 \mu \mathrm{mol} \mathrm{L}^{-1}$ DIN and DIP, respectively) than at the Mid-Atlantic Shelf stations west of $-70^{\circ} \mathrm{W}$ longitude $\left(0.92 \mu \mathrm{mol} \mathrm{L} \mathrm{L}^{-1}\right.$ and $0.20 \mu \mathrm{mol} \mathrm{L^{-1 }}$ DIN and DIP, respectively). During this cruise, DIN : DIP ratios were $<$ 16 at all but 4 stations where DIP was at or near the limit of analytical detection. Average volumetric rates of $\mathrm{N}_{2}$ fixation in surface-water samples ranged from $1.0 \mathrm{nmol} \mathrm{N}$ $\mathrm{L}^{-1} \mathrm{~d}^{-1}$ to $49.8 \mathrm{nmol} \mathrm{N} \mathrm{L}-1 \mathrm{~d}^{-1}$ (Table 5).

Water temperatures were cooler and salinity higher at the fluorescence maximum than in surface waters along the Mid-Atlantic Shelf but this was not always the case for 


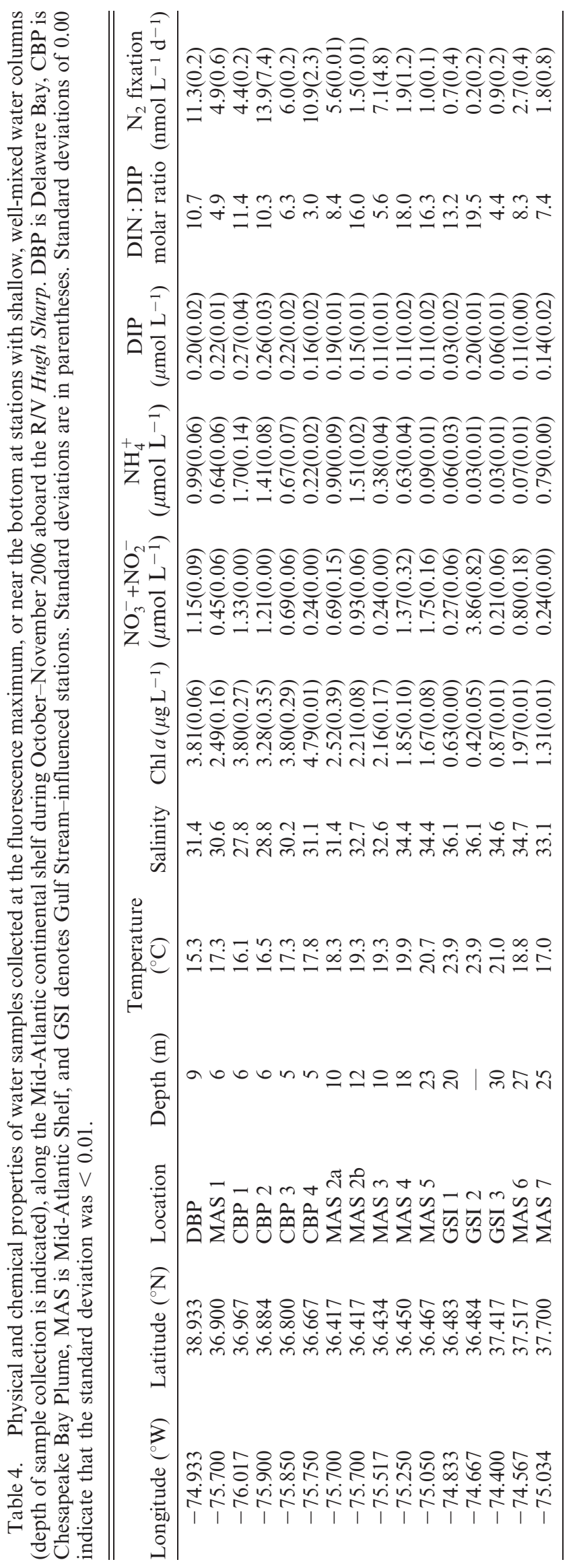

Georges Bank where the water column was well-mixed (Table 6). Water temperatures ranged from 8.4 to 20.9 and salinity ranged from 30.7 to 35.5 at the fluorescence maximum. DIN concentrations ranged from $0.16 \mu \mathrm{mol} \mathrm{N}$ $\mathrm{L}^{-1}$ to $9.51 \mu \mathrm{mol} \mathrm{N} \mathrm{L}-1$ and DIP concentrations ranged from $0.03 \mu \mathrm{mol} \mathrm{N} \mathrm{L}{ }^{-1}$ to $1.91 \mu \mathrm{mol} \mathrm{P} \mathrm{L}^{-1}$ in samples collected from the fluorescence maximum. As for surface waters, DIN: DIP ratios were $\leq 16$. Average volumetric rates of $\mathrm{N}_{2}$ fixation at the fluorescence maximum ranged from $0.3 \mathrm{nmol} \mathrm{N} \mathrm{L}{ }^{-1} \mathrm{~d}^{-1}$ to $20.3 \mathrm{nmol} \mathrm{N} \mathrm{L}{ }^{-1} \mathrm{~d}^{-1}$, lower than the range observed in surface waters. Depthintegrated $\mathrm{N}_{2}$ fixation rates in August 2009 ranged from $19.6 \mu \mathrm{mol} \mathrm{N} \mathrm{m}{ }^{-2} \mathrm{~d}^{-1}$ to $837.9 \mu \mathrm{mol} \mathrm{N} \mathrm{m} \mathrm{N}^{-2} \mathrm{~d}^{-1}$ (Fig. 3; Table 5), with the highest depth integrated $\mathrm{N}_{2}$ fixation rates measured at a station on Georges Bank.

When we compared $\mathrm{N}_{2}$ fixation rates with DIN concentrations (Fig. 4A,C) and temperature (Fig. 4B,D), in samples collected in surface water (Fig. 4A,B) and at the fluorescence maximum (Fig. 4C,D) for all three cruises, we observed that the highest rates of $\mathrm{N}_{2}$ fixation were measured in samples where DIN concentrations were lowest and temperatures were highest; however, there was no significant correlation between $\mathrm{N}_{2}$ fixation and temperature or DIN concentration for any of the cruises in surface waters or at the fluorescence maximum $(p>0.05)$. We observed no relationship between DIP concentrations and rates of $\mathrm{N}_{2}$ fixation during individual cruises or in the pooled data.

NifH gene copies were quantified using qPCR and previously used primer-probe sets from samples collected during July 2006 and August 2009. Unicellular $\mathrm{N}_{2}$-fixing group A cyanobacteria (UCYN-A) was the most abundant diazotroph quantified in the study area during both cruises. UCYN-A nifH gene copies ranged from not quantifiable to $3.5 \times 10^{7}$ gene copies $\mathrm{L}^{-1}$ (Table 7). The highest numbers of gene copies detected were from samples collected from Mid-Atlantic shelf waters during August 2009. Gene copies from the tropical diazotrophs, Trichodesmium and Richelia-Hemiaulus associations, were also quantifiable throughout the study area with the exception of stations within the Chesapeake Bay influenced region. Although high rates of $\mathrm{N}_{2}$ fixation were observed in the CBP area, the number of gene copies retrieved by qPCR was low. Subsequent sequencing of extracted DNA from these stations identified genes from UCYN-A cyanobacteria, and $\alpha$ and $\gamma$ proteobacteria (Fig. 5).

\section{Discussion}

Although oligotrophic tropical and subtropical marine environments depleted in DIN, and eutrophic fresh and brackish water environments enriched in phosphorus (P), have been thought to be primary sites for $\mathrm{N}_{2}$ fixation (Howarth et al. 1988; Paerl 2008; Conley et al. 2009), we found active $\mathrm{N}_{2}$ fixation in this temperate coastal marine system even where DIN concentrations were measurable in surface waters (range was $0.13 \mu \mathrm{mol} \mathrm{L}^{-1}$ to $5.90 \mu \mathrm{mol} \mathrm{L}^{-1}$; Tables 1, 3, and 5) and at the fluorescence maximum (Tables 2, 4, and 6). In 2006, we found that $\mathrm{N}_{2}$ fixation rates were often high (Fig. 1; Tables 1-4) and that nifH 


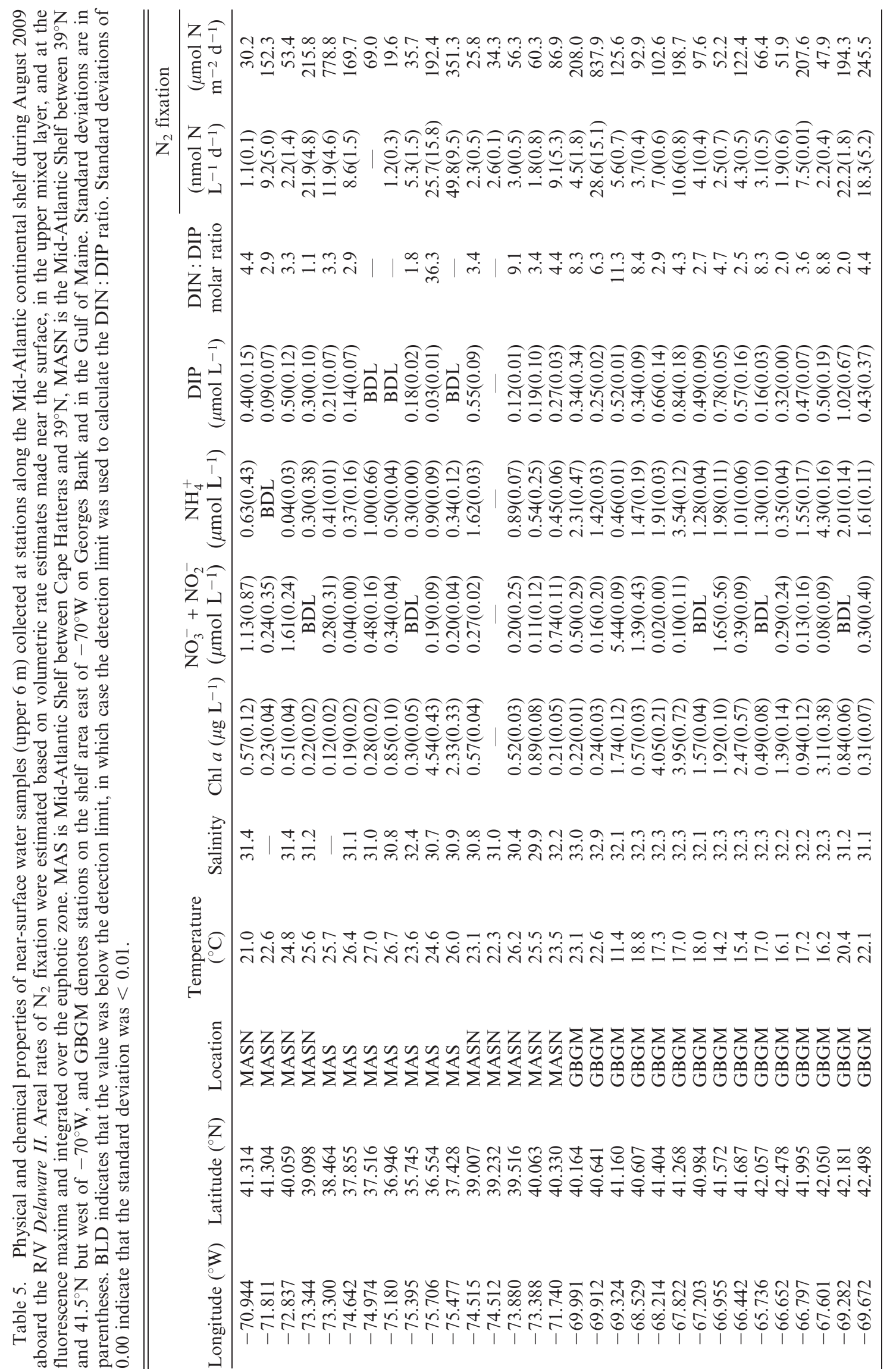




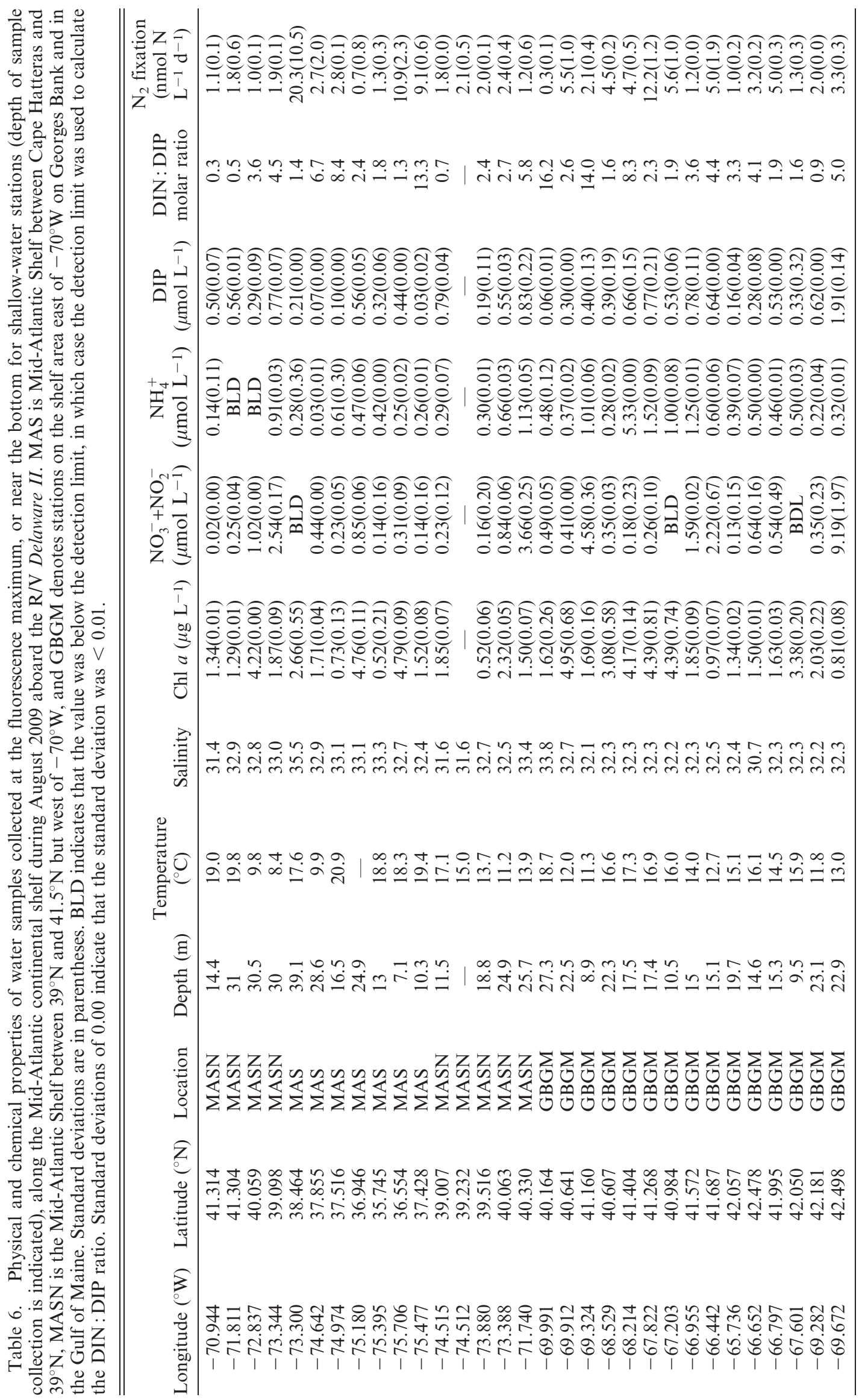




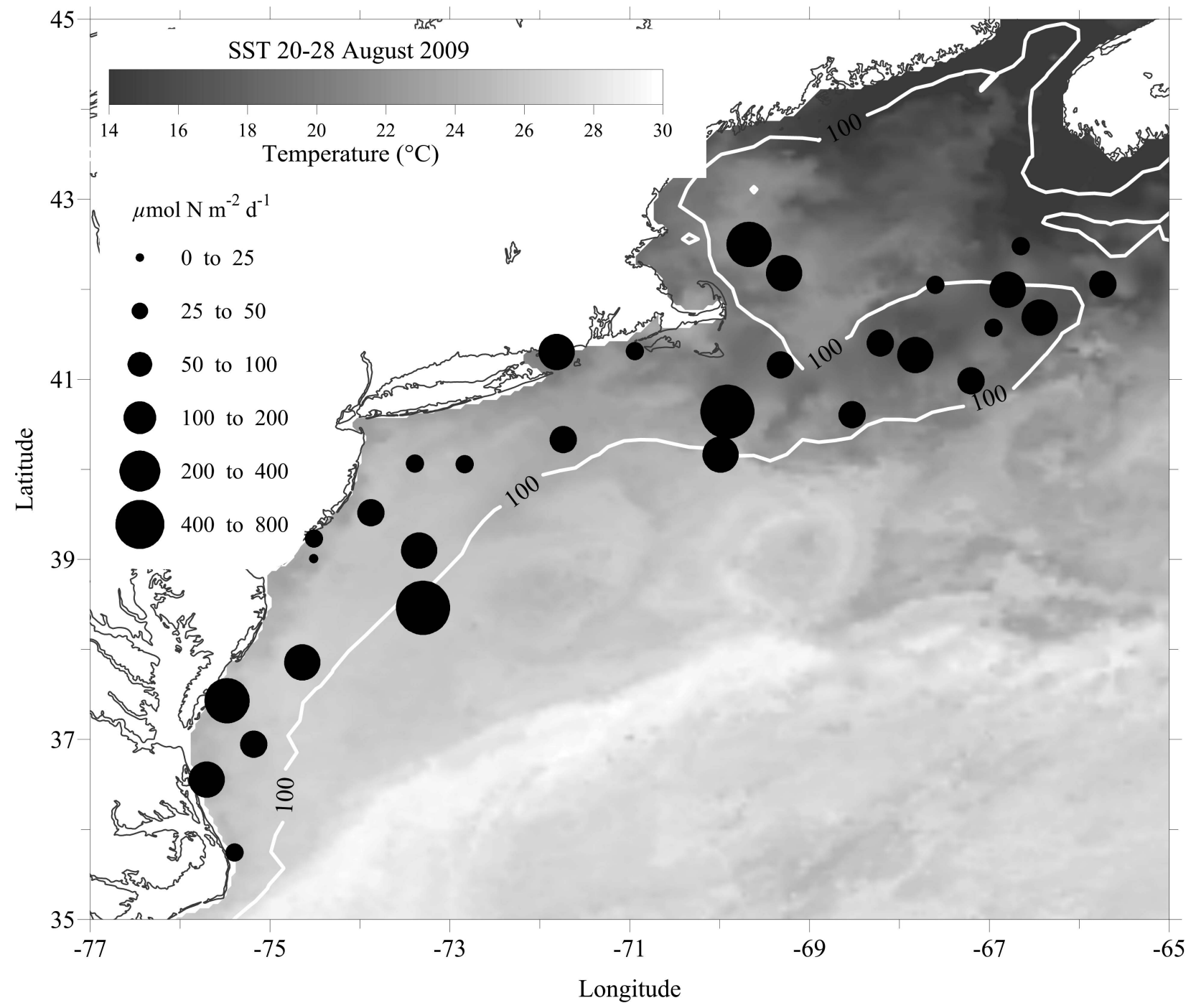

Fig. 3. Areal rates of $\mathrm{N}_{2}$ fixation $\left(\mu \mathrm{mol} \mathrm{N} \mathrm{m} \mathrm{N}^{-2} \mathrm{~d}^{-1}\right)$ in surface waters collected from the Mid-Atlantic shelf waters between Cape Hatteras and Georges Bank in August 2009, superimposed upon a weekly averaged sea surface temperature (SST) field from satellite observations made during the field campaign.

gene copies were abundant (Table 7) in (1) areas influenced by the Chesapeake Bay (CBP) or the Delaware Bay plumes (DBP), (2) Gulf Stream-influenced waters (GSI), and (3) Mid-Atlantic shelf waters (MAS). During our wider survey in 2009, we found that high rates of $\mathrm{N}_{2}$ fixation (Fig. 3; Tables 5 and 6) and abundant nifH gene copies (Table 7) extended into coastal waters north (to almost $43^{\circ} \mathrm{N}$ ) and east (to $-65^{\circ} \mathrm{W}$ ) of the Delaware Bay plume, including the highly productive Georges Bank. Expression of nifH genes was previously observed primarily in oligotrophic waters in the temperate and subtropical Pacific (Church et al. 2005; Needoba et al. 2007) and the subtropical and tropical Atlantic Ocean (Langlois et al. 2005). Similarly, rates of pelagic marine $\mathrm{N}_{2}$ fixation have been primarily reported from tropical and subtropical oligotrophic gyres (Table 8; Mahaffey et al. 2005; Carpenter and Capone 2008; Mulholland and Lomas 2008).

$\mathrm{N}_{2}$ fixation rates in this study were generally higher in the well-lit surface mixed layer than at the depth of the fluorescence maximum, ranging from averages of $2.0 \mathrm{nmol}$ $\mathrm{N} \mathrm{L}^{-1} \mathrm{~d}^{-1}$ to $39.0 \mathrm{nmol} \mathrm{N} \mathrm{L} \mathrm{N}^{-1} \mathrm{~d}^{-1}$ during summer (July 2006), $1.3 \mathrm{nmol} \mathrm{N} \mathrm{L}-1 \mathrm{~d}^{-1}$ to $20.3 \mathrm{nmol} \mathrm{N} \mathrm{L}-1 \mathrm{~d}^{-1}$ during

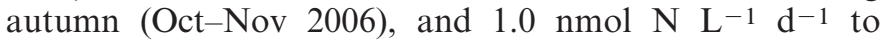
$49.8 \mathrm{nmol} \mathrm{N} \mathrm{L} \mathrm{N}^{-1}$ during August 2009 (the limit of analytic detection was $\left.\sim 0.1 \mathrm{nmol} \mathrm{N} \mathrm{L}^{-1} \mathrm{~d}^{-1}\right)$. This is consistent with the observation that cyanobacterial diazotrophs (and most cyanobacteria) are predominantly photoautotrophic (Zehr et al. 2008). Rates reported here from the euphotic zone are also within the range or higher than those reported previously for the tropical and subtropical Atlantic Ocean and other areas of the world's oceans (Table 8), but not as high as some of those reported from tropical coastal waters north of Australia (Montoya et al. 2004).

Temperature is thought to limit planktonic $\mathrm{N}_{2}$ fixation by some marine cyanobacteria (Staal et al. 2003; Breitbarth et al. 2007; Moisander et al. 2010). Consistent with this idea, during cruises on the continental shelf between the 

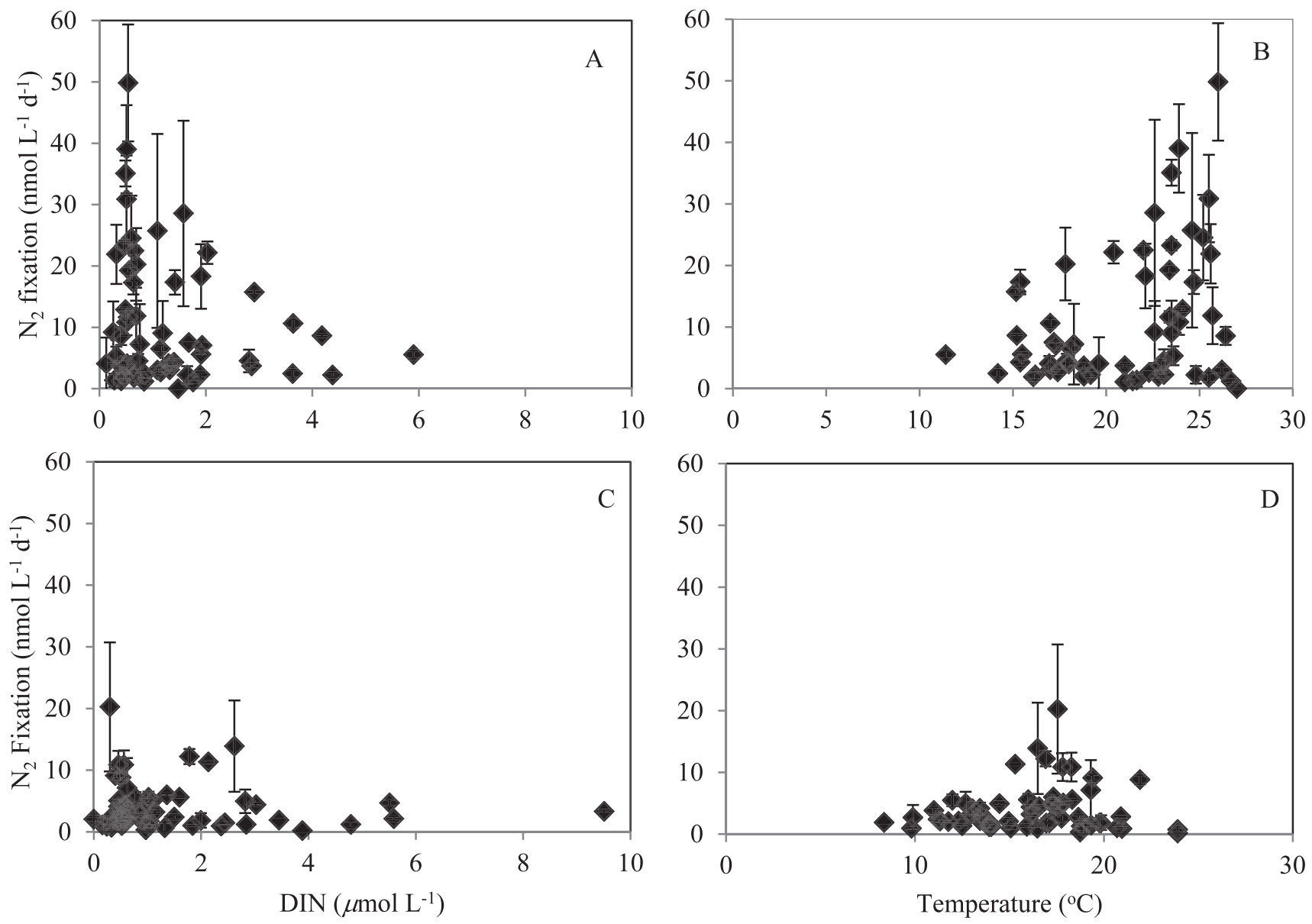

Fig. 4. Relationship between volumetric rates of $\mathrm{N}_{2}$ fixation (nmol $\mathrm{L}^{-1} \mathrm{~d}^{-1}$ ) and (A) DIN concentrations and (B) water temperature, in samples collected from near the surface (upper $5 \mathrm{~m}$ ), and $(\mathrm{C}, \mathrm{D})$ the relationship between these same parameters in samples collected from the fluorescence maximum or near the bottom during all three cruises (summer and autumn 2006 and autumn 2009).

Chesapeake Bay and Delaware Bay plumes, higher rates of $\mathrm{N}_{2}$ fixation were measured in summer when surface-water temperatures were higher $\left(23.5^{\circ} \mathrm{C} \pm 1.2^{\circ} \mathrm{C}\right)$ than in autumn, when water temperatures were on average $6^{\circ} \mathrm{C}$ cooler $\left(17.8^{\circ} \mathrm{C} \pm 2.0^{\circ} \mathrm{C}\right.$; Figs. 1,3$)$. Temperature and $\mathrm{N}_{2}$ fixation rates were positively related in July (Fig. 2A). When water temperatures were below $18^{\circ} \mathrm{C}, \mathrm{N}_{2}$ fixation was always $<$ $9 \mathrm{nmol} \mathrm{N} \mathrm{L}{ }^{-1} \mathrm{~d}^{-1}$, and when temperatures were above $18^{\circ} \mathrm{C}, \mathrm{N}_{2}$ fixation rates were higher, ranging from $2 \mathrm{nmol} \mathrm{N}$ $\mathrm{L}^{-1} \mathrm{~d}^{-1}$ to $39.0 \mathrm{nmol} \mathrm{N} \mathrm{L} \mathrm{N}^{-1} \mathrm{~d}^{-1}$, consistent with the hypothesis that water temperature plays a role in controlling rates of $\mathrm{N}_{2}$ fixation. However, all of rate measurements made at water temperatures $<18^{\circ} \mathrm{C}$ during July were from samples collected at the fluorescence maximum, where PAR may have limited $\mathrm{N}_{2}$ fixation by phototrophs. In contrast, during October-November, the highest rates of $\mathrm{N}_{2}$ fixation were measured at stations with lower water temperatures $\left(15-18^{\circ} \mathrm{C}\right.$; Fig. 2B). During October-November, surface waters were cooling and water temperatures at the fluorescence maximum were often as warm as, or warmer than, those recorded in surface waters. $\mathrm{N}_{2}$ fixation rates were usually, but not always, higher in the upper $10 \mathrm{~m}$ (Table 3) than in samples collected from deeper than $12 \mathrm{~m}$
(Table 4), which suggested that light was an important factor controlling the spatial distribution of $\mathrm{N}_{2}$ fixation. During our expanded cruise track in 2009, when there was a wider range in surface-water temperatures $\left(11.4^{\circ} \mathrm{C}\right.$ to $27.0^{\circ} \mathrm{C}$ ), there was no relationship between $\mathrm{N}_{2}$ fixation rates in surface-water samples and surface-water temperature $(p>0.05 ;$ Fig. 4$)$. In fact, many of the highest $\mathrm{N}_{2}$ fixation rates were measured in cooler waters (Fig. 3; Tables 5 and 6). The high rates of coastal $\mathrm{N}_{2}$ fixation reported here over a broader temperature domain are consistent with those from two coastal stations in the temperate English Channel $\left(\sim 50^{\circ} \mathrm{N}\right.$ latitude $)$, where measured planktonic $\mathrm{N}_{2}$ fixation rates were $18.9 \pm 0.1 \mathrm{nmol}$ $\mathrm{N} \mathrm{L}^{-1} \mathrm{~d}^{-1}$ and $20.0 \mathrm{nmol} \mathrm{N} \mathrm{L}{ }^{-1} \mathrm{~d}^{-1}$ (water temperatures were $18.8^{\circ} \mathrm{C}$ and $20.1^{\circ} \mathrm{C}$, respectively; Rees et al. 2009).

Although oligotrophic tropical and subtropical marine environments depleted in DIN, and eutrophic fresh and brackish water environments enriched in $\mathrm{P}$, have been thought to be primary sites for $\mathrm{N}_{2}$ fixation (Howarth et al. 1988; Zehr and Paerl 2008; Conley et al. 2009), we found active $\mathrm{N}_{2}$ fixation in the presence of DIN and in the absence of $\mathrm{P}$ enrichment in this temperate coastal marine system. In this study the DIN : DIP ratio was usually $<16$, 
Table 7. NifH gene copies from samples collected during July 2006 and August 2009 on the western Mid-Atlantic shelf. UCYN-A were most abundant throughout the study area. NifH genes from Group C cyanobacteria, Chaetoceros-Calothrix, and RhizosoleniaRichelia associations were not detected (nd) in any of the 2006 samples so were not probed in 2009. Group B cyanobacteria nifH gene copies were detected but not quantifiable (dnq) during 2006 and so were not used in 2009. Trichodesmium nifH gene copies were quantified in all but the CBP samples. NifH genes from Richelia-Hemiaulus associations were quantifiable in all but the GBGM region.

\begin{tabular}{|c|c|c|c|}
\hline \multirow[b]{2}{*}{ Station } & \multicolumn{3}{|c|}{ (nifH copies $\mathrm{L}^{-1}$ ) } \\
\hline & UCYN-A & Trichodesmium & Richelia-Hemiaulus \\
\hline \multicolumn{4}{|c|}{ Mid-Atlantic Shelf waters (MAS): Jul 2006} \\
\hline $\begin{array}{l}\text { MAS } 1 ; 37.695^{\circ} \mathrm{N} ;-75.298^{\circ} \mathrm{W} \\
\text { MAS } 2 ; 37.631^{\circ} \mathrm{N} ;-75.152^{\circ} \mathrm{W} \\
\text { MAS } 3 ; 37.519^{\circ} \mathrm{N} ;-75.050^{\circ} \mathrm{W} \\
\text { MAS } 4 ; 38.042^{\circ} \mathrm{N} ;-74.299^{\circ} \mathrm{W} \\
\text { MAS 5; } 38.122^{\circ} \mathrm{N} ;-74.384^{\circ} \mathrm{W}\end{array}$ & $\begin{array}{l}1.72 \times 10^{4} \\
\mathrm{dnq} \\
6.23 \times 10^{5} \\
1.63 \times 10^{6} \\
5.40 \times 10^{4}\end{array}$ & $\begin{array}{l}2.65 \times 10^{3} \\
\text { dnq } \\
\text { dnq } \\
\text { nd }\end{array}$ & $\begin{array}{l}\text { nd } \\
1.67 \times 10^{4} \\
2.34 \times 10^{3} \\
1.62 \times 10^{3} \\
\text { nd }\end{array}$ \\
\hline \multicolumn{4}{|c|}{ Mid-Atlantic Shelf waters (MAS): Aug 2009} \\
\hline $\begin{array}{l}\text { Sta. } 37 ; 36.554^{\circ} \mathrm{N} ;-75.706^{\circ} \mathrm{W} \\
\text { Sta. } 38 ; 37.428^{\circ} \mathrm{N} ;-75.476^{\circ} \mathrm{W}\end{array}$ & $\begin{array}{l}3.5 \times 10^{7} \\
2.5 \times 10^{7}\end{array}$ & $\begin{array}{l}\text { nd } \\
\text { nd }\end{array}$ & $\begin{array}{l}4.2 \times 10^{3} \\
1.6 \times 10^{5}\end{array}$ \\
\hline $\begin{array}{l}\text { Gulf Stream influence }(\mathrm{GSI}) \text { : Jul } 2 \\
\text { GSI } 1 ; 36.686^{\circ} \mathrm{N} ;-74.683^{\circ} \mathrm{W} \\
\text { GSI } 2 ; 36.627^{\circ} \mathrm{N} ;-74.863^{\circ} \mathrm{W} \\
\text { GSI } 3 ; 36.601^{\circ} \mathrm{N} ;-75.058^{\circ} \mathrm{W} \\
\text { GSI } 4 ; 36.532^{\circ} \mathrm{N} ;-75.273^{\circ} \mathrm{W}\end{array}$ & $\begin{array}{l}1.20 \times 10^{6} \\
1.96 \times 10^{5} \\
1.10 \times 10^{4} \\
7.65 \times 10^{4}\end{array}$ & $\begin{array}{l}\text { nd } \\
7.47 \times 10^{2} \\
1.27 \times 10^{5} \\
7.63 \times 10^{2}\end{array}$ & $\begin{array}{l}3.10 \times 10^{3} \\
3.72 \times 10^{4} \\
1.97 \times 10^{4} \\
1.80 \times 10^{4}\end{array}$ \\
\hline $\begin{array}{l}\text { Chesapeake Bay Plume influence } \\
\text { CBP } 1 ; 36.972^{\circ} \mathrm{N} ;-76.019^{\circ} \mathrm{W} \\
\text { CBP } 2 ; 36.900^{\circ} \mathrm{N} ;-75.908^{\circ} \mathrm{W} \\
\text { CBP } 3 ; 36.803^{\circ} \mathrm{N} ;-75.857^{\circ} \mathrm{W} \\
\text { CBP } 4 ; 36.671^{\circ} \mathrm{N} ;-75.766^{\circ} \mathrm{W} \\
\text { CBP } 5 ; 36.885^{\circ} \mathrm{N} ;-75.719^{\circ} \mathrm{W}\end{array}$ & $\begin{array}{l}1.93 \times 10^{4} \\
\mathrm{dnq} \\
2.52 \times 10^{4} \\
3.03 \times 10^{3} \\
2.84 \times 10^{4}\end{array}$ & $\begin{array}{l}\text { nd } \\
\text { nd } \\
\text { nd } \\
\text { nd } \\
\text { nd }\end{array}$ & $\begin{array}{l}\text { dnq } \\
\text { nd } \\
\text { nd } \\
\text { nd } \\
\text { nd }\end{array}$ \\
\hline $\begin{array}{l}\text { Mid-Atlantic Shelf waters (north } \\
\text { Sta. } 44 ; 39.516^{\circ} \mathrm{N} ;-73.880^{\circ} \mathrm{W} \\
\text { Sta. } 50 ; 40.330^{\circ} \mathrm{N} ;-71.740^{\circ} \mathrm{W}\end{array}$ & $\begin{array}{l}2009 \\
1.7 \times 10^{5} \\
8.2 \times 10^{4}\end{array}$ & $\begin{array}{l}\text { nd } \\
9.1 \times 10^{4}\end{array}$ & $\begin{array}{l}7.9 \times 10^{4} \\
2.9 \times 10^{3}\end{array}$ \\
\hline $\begin{array}{l}\text { Georges Bank and Gulf of Maine } \\
\text { Sta. } 65 ; 40.607^{\circ} \mathrm{N} ;-68.529^{\circ} \mathrm{W} \\
\text { Sta. } 72 ; 41.268^{\circ} \mathrm{N} ;-67.822^{\circ} \mathrm{W} \\
\text { Sta. } 75 ; 40.984^{\circ} \mathrm{N} ;-67.203^{\circ} \mathrm{W} \\
\text { Sta. } 92 ; 41.995^{\circ} \mathrm{N} ;-66.797^{\circ} \mathrm{W} \\
\text { Sta. } 99 ; 42.181^{\circ} \mathrm{N} ;-69.282^{\circ} \mathrm{W}\end{array}$ & $\begin{array}{l}\text { GM): Aug } 2 \\
6.2 \times 10^{5} \\
2.3 \times 10^{2} \\
4.6 \times 10^{5} \\
4.3 \times 10^{5} \\
8.5 \times 10^{5}\end{array}$ & $\begin{array}{l}\text { dnq } \\
\text { nd } \\
1.1 \times 10^{2} \\
\text { nd } \\
\text { dnq }\end{array}$ & $\begin{array}{l}\text { nd } \\
\text { nd } \\
\text { nd } \\
\text { dnq } \\
\text { nd }\end{array}$ \\
\hline
\end{tabular}

suggesting $\mathrm{N}$ limitation, but there was no relationship between $\mathrm{N}_{2}$ fixation rates and the DIN : DIP ratio or the DIN concentration during any of the cruises $(p>0.05)$. Consistent with our results, nifH gene expression has been observed in the temperate Pacific (Church et al. 2005; Needoba et al. 2007) and Atlantic (Langlois et al. 2005) oceans and active $\mathrm{N}_{2}$ fixation has now been observed in $\mathrm{NO}_{3}^{-}$-replete $(\sim 10-\mu \mathrm{mol} \mathrm{L}-1)$ waters below the upper mixed layer in the eastern tropical North Atlantic Ocean (5 stations; Voss et al. 2004), in surface waters in the English Channel (2 stations; Rees et al. 2009), and in the Mekong River plume in the South China Sea (22 stations over two seasons; Grosse et al. 2010). In culture studies, Trichodesmium has been shown to be capable of fixing $\mathrm{N}_{2}$ in the presence of up to $20 \mu \mathrm{mol} \mathrm{N} \mathrm{L}{ }^{-1} \mathrm{DIN}$, although rates are reduced above about $5 \mu \mathrm{mol} \mathrm{L}-1$ DIN (Mulholland et al. 2001; Holl and Montoya 2005). Concentrations of DIN in surface waters over the study area were never depleted; average DIN concentrations in July were $0.54 \mu \mathrm{mol} \mathrm{N} \mathrm{L}-1$ $\left( \pm 0.09 \mu \mathrm{mol} \mathrm{N} \mathrm{L}{ }^{-1}\right)$ and concentrations ranged from $0.40 \mu \mathrm{mol} \mathrm{N} \mathrm{L}{ }^{-1}$ to $2.37 \mu \mathrm{mol} \mathrm{N} \mathrm{L}-1$ (Tables 1 and 2).
During the October-November cruise, average DIN concentrations were higher $\left(1.4 \mu \mathrm{mol} \mathrm{N} \mathrm{L}{ }^{-1} ; \pm 1.1 \mu \mathrm{mol}\right.$ $\mathrm{N} \mathrm{L}^{-1}$ ) with concentrations ranging from $0.06 \mu \mathrm{mol} \mathrm{N} \mathrm{L}{ }^{-1}$ to $4.18 \mu \mathrm{mol} \mathrm{N} \mathrm{L}{ }^{-1}$ (Tables 3 and 4). Over the expanded study area during 2009, DIN concentrations ranged from $0.16 \mu \mathrm{mol} \mathrm{N} \mathrm{L}-1$ to $9.51 \mu \mathrm{mol} \mathrm{N} \mathrm{L}^{-1}$ (Tables 5 and 6). Based on these data, the absolute depletion of DIN appears unnecessary for active marine $\mathrm{N}_{2}$ fixation; however, the nutrient thresholds above which $\mathrm{N}_{2}$ fixation is inhibited remain to be elucidated for most marine diazotrophs.

UCYN-A were the most abundant diazotroph throughout the study area, ranging from the limit of detection to $3.5 \times 10^{7}$ nifH gene copies $\mathrm{L}^{-1}$ (Table 7), among the highest abundances ever observed (Carpenter and Capone 2008; Moisander et al. 2010). The highest UCYN-A nifH abundances were measured at the southernmost coastal stations, where the highest rates of $\mathrm{N}_{2}$ fixation were also observed in August 2009 (Table 7; Fig. 3; see also Table 5). This group was also abundant in samples from stations on Georges Bank and in the Gulf of Maine (latitudes $>40^{\circ} \mathrm{N}$ ), where surface-water temperatures were between $17.0^{\circ} \mathrm{C}$ and 


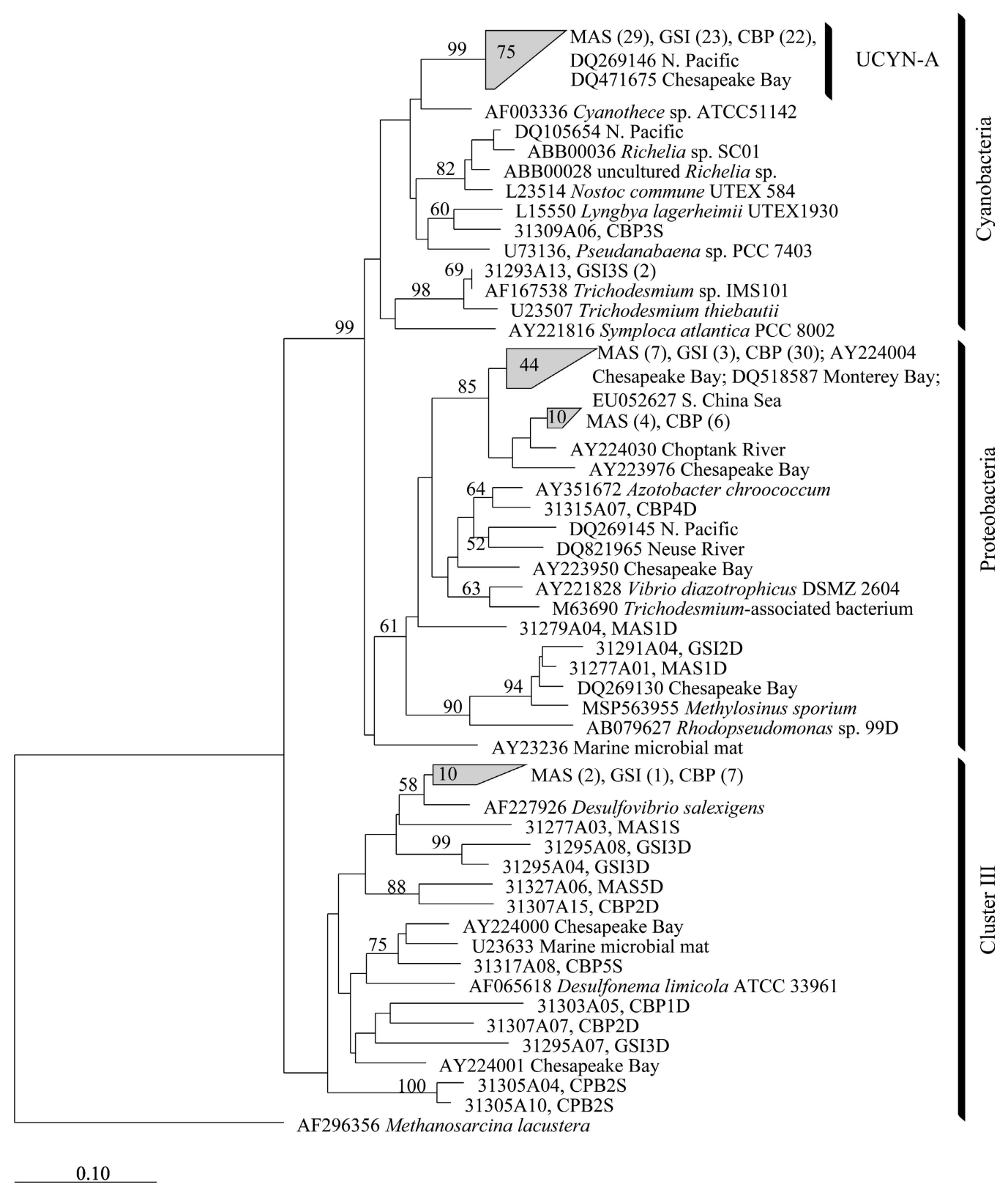

Fig. 5. Neighbor-joining tree of nifH amino-acid sequences obtained from samples collected in July 2006. Numbers in the triangles are the number of sequences in those groups. Bootstrap values (500 replicates) $>50 \%$ are shown at the respective nodes.

$20.6^{\circ} \mathrm{C}$, consistent with observations that this organism thrives at cooler water temperatures than other marine diazotrophs (Langlois et al. 2008; Moisander et al. 2010). $\mathrm{NifH}$ gene sequences clustering with UCYN-A were previously reported from two sites in the temperate English Channel (Rees et al. 2009), which suggests that $\mathrm{N}_{2}$ fixation in North Atlantic coastal waters may be widespread. Unlike other cyanobacterial $\mathrm{N}_{2}$ fixers, UCYN-A is a photoheterotroph that is likely symbiotic (Zehr et al. 2008; Tripp et al. 2010) and this has important implications with regards to coupled $\mathrm{N}$ and $\mathrm{C}$ dynamics in systems where they are abundant.

Trichodesmium nifH genes were detected throughout the study area except in the Chesapeake Bay-influenced region. This is consistent with the recent observation that these diazotrophs may be more widespread than previously thought (Davis and McGillicuddy 2006). Hemiaulus-Richelia (diatom-cyanobacterial symbioses) associations were also detected throughout the study area, but the highest concentrations were measured at stations west of $-71^{\circ} \mathrm{W}$, consistent with their abundance in river plumes and coastal regions with high silicate concentrations (Foster et al. 2007). Although detected, nifH gene abundances for Trichodesmium and Richelia were low or undetectable at many stations on Georges Bank, in the Gulf of Maine, and in the Chesapeake Bay plume-influenced region. Group B (Crocosphaera) cyanobacteria were detected but only at very low levels, near the limit of detection, during 2006.

The highest $\mathrm{N}_{2}$ fixation rates during July 2006 were measured at the CBP-influenced stations where only 
Table 8. Ranges of water-column $\mathrm{N}_{2}$ fixation rates measured in other oceanographic provinces. Rates are presented as hourly rates because it is unclear whether all unicellular diazotrophs exhibit diel periodicity in $\mathrm{N}_{2}$ fixation (updated from Mulholland et al. 2006; references can be found in the Web Appendix at www.aslo.org/lo/toc/vol_57/issue_4/1067a.pdf).

\begin{tabular}{|c|c|c|c|c|c|}
\hline Date & Location & Depth & $\begin{array}{c}\mathrm{N}_{2} \text { fixation } \\
\left(\mathrm{nmol} \mathrm{L}^{-1} \mathrm{~h}^{-1}\right)\end{array}$ & Method* & Reference \\
\hline \multicolumn{6}{|l|}{ Atlantic Ocean: } \\
\hline Spring 2002 & Tropical N Atlantic & euphotic zone & $\sim 0.147$ & AR & Falcon et al. 2004 \\
\hline Summer 2001 & Tropical N Atlantic & euphotic zone & $0.025-0.045$ & ${ }^{15} \mathrm{~N}_{2}$ & Falcon et al. 2004 \\
\hline $\begin{array}{l}\text { Seasonally } 2001- \\
\quad 2003\end{array}$ & Western tropical N Atlantic & euphotic zone & $0-1.2$ & ${ }^{15} \mathrm{~N}_{2}$ & $\begin{array}{l}\text { Subramaniam et al. } \\
\quad 2008\end{array}$ \\
\hline Autumn 2007 & Eastern N Atlantic & surface & $0-6.3$ & ${ }^{15} \mathrm{~N}_{2}$ & Turk et al. 2011 \\
\hline Autumn 2002 & Tropical N Atlantic & upper $100 \mathrm{~m}$ & up to 3.1 & ${ }_{15} \mathrm{~N}_{2}$ & Voss et al. 2004 \\
\hline Jul 2006 & $\begin{array}{l}\text { Coastal eastern temperate } \mathrm{N} \\
\text { Atlantic }\end{array}$ & surface & $0.79-0.83$ & ${ }^{15} \mathrm{~N}_{2}$ & Rees et al. 2009 \\
\hline Jun 2006 & Tropical N Atlantic & surface & $0.02-0.053$ & ${ }^{15} \mathrm{~N}_{2}$ & Goebel et al. $2010^{\dagger}$ \\
\hline Winter 2000 & $\begin{array}{l}\text { Subtropical and tropical } \\
\text { eastern N Atlantic }\end{array}$ & $3-4 \mathrm{~m}$ & $0-0.059$ & $\mathrm{AR}$ & Staal et al. 2007 \\
\hline Spring 2007 & Eastern N Atlantic & surface & $0.300 \pm 0.115$ & ${ }^{15} \mathrm{~N}_{2}$ & Ibello et al. 2010 \\
\hline Jul 2006 & Coastal western N Atlantic & euphotic zone & $0.03-1.84$ & ${ }^{15} \mathrm{~N}_{2}$ & This study \\
\hline Oct-Nov 2006 & Coastal western N Atlantic & euphotic zone & $0.01-1.02$ & $15 \mathrm{~N}_{2}$ & This study \\
\hline Aug 2009 & Coastal western N Atlantic & euphotic zone & $0.02-3.20$ & ${ }^{15} \mathrm{~N}_{2}$ & This study \\
\hline \multicolumn{6}{|l|}{ Pacific Ocean: } \\
\hline Jul 2000 & Subtropical N Pacific & $25 \mathrm{~m}$ & $0.010-0.016$ & ${ }^{15} \mathrm{~N}_{2}$ & Zehr et al. 2001 \\
\hline $\begin{array}{l}\text { Seasonally } 2000- \\
2001\end{array}$ & Subtropical N Pacific & upper $100 \mathrm{~m}$ & $0-0.092$ & $15 \mathrm{~N}_{2}$ & Dore et al. $2002 \dagger$ \\
\hline Autumn 2002 & Subtropical N Pacific & euphotic zone & $\sim 0.003$ & AR & Falcon et al. 2004 \\
\hline 2000-2002 & $\begin{array}{l}\text { Subtropical N Pacific and } \\
\text { Kaneohe Bay }\end{array}$ & $25 \mathrm{~m}$ and Surface & $0.01-0.15$ & ${ }^{15} \mathrm{~N}_{2}$ & Montoya et al. 2004 \\
\hline Jun-Jul 2002 & Eastern N Pacific & euphotic zone & $0.047-1.85$ & ${ }^{15} \mathrm{~N}_{2}$ & Montoya et al. 2004 \\
\hline Winter 2007 & $\begin{array}{l}\text { Subtropical and tropical } \\
\text { western N Pacific }\end{array}$ & euphotic zone & $0-0.15$ & ${ }^{15} \mathrm{~N}_{2}$ & Shiozaki et al. $2009 \dagger$ \\
\hline 2006-2007 & $\begin{array}{l}\text { Temperate to equatorial } \mathrm{N} \\
\text { Pacific }\end{array}$ & euphotic zone & $0.04-1.17$ & ${ }^{15} \mathrm{~N}_{2}$ & Shiozaki et al. $2010 \dagger$ \\
\hline 2000-2001 & Subtropical N Pacific & $25 \mathrm{~m}$ & $0.014-0.095$ & ${ }^{15} \mathrm{~N}_{2}$ & Zehr et al. 2007t \\
\hline 2004-2007 monthly & Subtropical N Pacific & upper $25 \mathrm{~m}$ & $0.02-0.46$ & ${ }^{15} \mathrm{~N}_{2}$ & Church et al. $2009 \dagger$ \\
\hline Jul 2005 & Subtropical N Pacific & $5 \mathrm{~m}$ & $0.18-0.95$ & $15 \mathrm{~N}_{2}$ & Fong et al. $2008 \dagger$ \\
\hline 2001-2002 & Kane'ohe Bay & surface & $0.029-0.048$ & ${ }^{15} \mathrm{~N}_{2}$ & Zehr et al. $2007 t$ \\
\hline Autumn 1999 & Arafura Sea & fluorescence maximum & $20-62$ & $15 \mathrm{~N}_{2}$ & Montoya et al. 2004 \\
\hline Summer 2006 & Equatorial Pacific & euphotic zone & $0.002-25.42$ & $15 \mathrm{~N}_{2}$ & Bonnet et al. $2009 \dagger$ \\
\hline $\begin{array}{l}\text { Summer-winter } \\
2004-2005\end{array}$ & Western Pacific & - & $0.04-0.83$ & $\mathrm{AR}$ & Kitajima et al. $2009 \dagger$ \\
\hline Oct 2005 & Temperate N Pacific & $10 \mathrm{~m}$ & $0.006-0.013$ & ${ }^{15} \mathrm{~N}_{2}$ & Needoba et al. $2007 \dagger$ \\
\hline Jul-Aug & Subtropical N Pacific & upper $50 \mathrm{~m}$ & $0.001-0.86$ & ${ }^{15} \mathrm{~N}$ & $\begin{array}{l}\text { Watkins-Brandt et al. } \\
2011 \uparrow,+\end{array}$ \\
\hline Autumn 2004 & South Pacific & euphotic zone & $0-0.15$ & ${ }^{15} \mathrm{~N}_{2}$ & $\begin{array}{l}\text { Raimbault and Garcia } \\
2008 \dagger\end{array}$ \\
\hline Mar-Apr 2007 & Western S Pacific & surface & $0-4.5$ & ${ }^{15} \mathrm{~N}_{2}$ & Moisander et al. 2010 \\
\hline \multicolumn{6}{|l|}{ Indian Ocean: } \\
\hline Oct 2003 & Leeuwin Current & euphotic zone & $0.005-0.07$ & ${ }^{15} \mathrm{~N}_{2}$ & Holl et al. 2007 \\
\hline \multicolumn{6}{|l|}{ Mediterranean Sea: } \\
\hline May 2002 & E Mediterranean & $16 \mathrm{~m}$ & 5.38 & ${ }^{15} \mathrm{~N}_{2}$ & Rees et al. $2006 \S$ \\
\hline $\begin{array}{l}2003-2004(12 \\
\text { cruises) }\end{array}$ & NW Mediterranean & upper $60 \mathrm{~m}$ & $0.083-0.71$ & ${ }^{15} \mathrm{~N}_{2}$ & Garcia et al. $2006 \dagger$ \\
\hline Jun-Jul 2008 & Mediterranean & euphotic zone & $0.004-0.075$ & ${ }^{15} \mathrm{~N}_{2}$ & Bonnet et al. $2011 \dagger$ \\
\hline 2004-2008 & SE Mediterranean & euphotic zone & $0-0.013$ & $15 \mathrm{~N}_{2}$ & Yogev et al. $2011 \dagger$ \\
\hline Spring 2007 & Mediterranean & surface & $0.052 \pm 0.031$ & ${ }^{15} \mathrm{~N}_{2}$ & Ibello et al. 2010 \\
\hline 2004 & W Mediterranean & euphotic zone & $0.083-0.29$ & ${ }^{15} \mathrm{~N}_{2}$ & Sandroni et al. $2007 \dagger$ \\
\hline \multicolumn{6}{|l|}{ South China Sea: } \\
\hline $\begin{array}{l}\text { Apr } 2007 \text { (dry } \\
\text { season) }\end{array}$ & Mekong River Plume & surface & $0.11-22.77$ & ${ }^{15} \mathrm{~N}_{2}$ & Grosse et al. 2010 \\
\hline $\begin{array}{l}\text { Apr } 2007 \text { (wet } \\
\quad \text { season) }\end{array}$ & Mekong River Plume & surface & $0.06-5.05$ & ${ }^{15} \mathrm{~N}_{2}$ & Grosse et al. 2010 \\
\hline
\end{tabular}


Table 8. Continued.

\begin{tabular}{|c|c|c|c|c|c|}
\hline Date & Location & Depth & $\begin{array}{c}\mathrm{N}_{2} \text { fixation } \\
\left(\mathrm{nmol} \mathrm{L}^{-1} \mathrm{~h}^{-1}\right)\end{array}$ & Method* & Reference \\
\hline \multicolumn{6}{|l|}{ Baltic Sea: } \\
\hline Summer 1995-1996 & Central Baltic & surface & $0.19-5.6$ & $15 \mathrm{~N}_{2}$ & Ohlendieck et al. 2000 \\
\hline Summer 1998-1999 & Baltic Sea & $0-25 \mathrm{~m}$ & $0-7$ & ${ }^{15} \mathrm{~N}_{2}$ & Stal et al. 2003 \\
\hline \multicolumn{6}{|c|}{ Gulf of Mexico: } \\
\hline 2001-2003 & Gulf of Mexico & surface & $0.011-0.23$ & ${ }^{15} \mathrm{~N}_{2}$ & Mulholland et al. 2006 \\
\hline 2003 & Gulf of Mexico & fluorescence maximum & $0.044-0.063$ & $15 \mathrm{~N}_{2}$ & Mulholland et al. 2006 \\
\hline
\end{tabular}

modest concentrations of UCYN-A were quantifiable by qPCR (Table 7). UCYN-A-like nifH genes were previously found to be expressed at the mouth of the Chesapeake Bay (Short and Zehr 2007). Sequencing results suggest that diazotrophic $\alpha$ - and $\gamma$-like Proteobacteria, similar to those found previously in the Chesapeake Bay (Jenkins et al. 2004; Short et al. 2004; Short and Zehr 2007), may also have contributed to the high rates of $\mathrm{N}_{2}$ fixation in this region (Fig. 5). Expression of nifH by $\gamma$-Proteobacteria has been shown in other studies (Bird et al. 2005; Langlois et al. 2005), and therefore $\mathrm{N}_{2}$ fixation by these and other organisms present but not quantified may have contributed to the high volumetric rates of $\mathrm{N}_{2}$ fixation measured in the CBP during 2006. High precipitation in June 2006 prior to the cruise could have resulted in washout of microbes from the Chesapeake Bay and may have contributed to the high number of sequences similar to Proteobacteria found in the Chesapeake Bay plume during 2006 (Fig. 5). Two sequence types from the English Channel (Rees et al. 2009) had a > 97\% identity at the amino acid level with two Proteobacterial sequences found in this study, which suggests that this group of diazotrophs may also be widespread in North Atlantic coastal waters.

Areal rates of $\mathrm{N}_{2}$ fixation ranged from $40.9 \mu \mathrm{mol} N$ $\mathrm{m}^{-2} \mathrm{~d}^{-1}$ to $392.4 \mu \mathrm{mol} \mathrm{N} \mathrm{m}^{-2} \mathrm{~d}^{-1}$ for the area between Chesapeake and Delaware bays during 2006 (Fig. 1; Tables 1 and 3), and $19.6 \mu \mathrm{mol} \mathrm{N} \mathrm{m}^{-2} \mathrm{~d}^{-1}$ to $837.9 \mu \mathrm{mol}$ $\mathrm{N} \mathrm{m}{ }^{-2} \mathrm{~d}^{-1}$ over the area between about $35^{\circ} \mathrm{N}$ to $43^{\circ} \mathrm{N}$ and $-75^{\circ} \mathrm{W}$ to $-65^{\circ} \mathrm{W}$ during 2009 (Fig. 2; Table 5). These rates are within the range of areal $\mathrm{N}_{2}$ fixation rates reported for tropical and subtropical regions (range of 3.7-703 $\mu \mathrm{mol} \mathrm{N}$ $\mathrm{m}^{-2} \mathrm{~d}^{-1}$; Carpenter and Capone 2008), the tropical North Atlantic Ocean (average $239 \pm 38 \mu \mathrm{mol} \mathrm{N} \mathrm{m}{ }^{-2} \mathrm{~d}^{-1}$; Capone et al. 2005), and the temperate English Channel (average $350 \mu \mathrm{mol} \mathrm{N} \mathrm{m}{ }^{-2} \mathrm{~d}^{-1}$; Rees et al. 2009), and represent a substantial new $\mathrm{N}$ input into this ocean basin. In the area north of the Delaware Bay $\left(39-41.5^{\circ} \mathrm{N}\right)$ and west of $-70^{\circ} \mathrm{W}$, areal rates of $\mathrm{N}_{2}$ fixation were on average $79.5 \mu \mathrm{mol} \mathrm{N}$ $\mathrm{m}^{-2} \mathrm{~d}^{-1}$ (range was 30.2-215.8 $\mu \mathrm{mol} \mathrm{N} \mathrm{m}^{-2} \mathrm{~d}^{-1}$ ), lower than those measured between Delaware Bay and Cape Hatteras (average $230.9 \mu \mathrm{mol} \mathrm{N} \mathrm{m}{ }^{-2} \mathrm{~d}^{-1}$; range $=19.6$ $778.8 \mu \mathrm{mol} \mathrm{N} \mathrm{m}^{-2} \mathrm{~d}^{-1}$ between $35^{\circ} \mathrm{N}$ and $39^{\circ} \mathrm{N}$ ) during 2009. At latitudes $>40^{\circ} \mathrm{N}$ and east of $-70^{\circ} \mathrm{W}$, average areal rates of $\mathrm{N}_{2}$ fixation were $176.8 \mu \mathrm{mol} \mathrm{N} \mathrm{m}{ }^{-2} \mathrm{~d}^{-1}$ (range $=$
47.9-837.9 $\mu$ mol $\mathrm{N} \mathrm{m}^{-2} \mathrm{~d}^{-1}$ ), despite the markedly lower water temperatures in this region (Table 5).

Integrating over a year, we calculate a total $\mathrm{N}$ input of about $0.02 \mathrm{Tmol} \mathrm{N} \mathrm{yr}^{-1}$ from planktonic $\mathrm{N}_{2}$ fixation in the North American continental shelf waters between Cape Hatteras and Nova Scotia $\left(35-45^{\circ} \mathrm{N}\right.$ latitude). Although this region represents only about $6.4 \%$ of the total North Atlantic continental shelf area (and the North Atlantic includes about $20 \%$ of the global continental shelf area), $\mathrm{N}$ inputs from $\mathrm{N}_{2}$ fixation calculated for this region alone are about equal to those calculated previously for the entire North Atlantic continental shelf $\left(0.02 \mathrm{Tmol} \mathrm{N} \mathrm{yr}^{-1}\right.$; Nixon et al. 1996). Further, comparable rates of $\mathrm{N}_{2}$ fixation have been reported from the English Channel on the other side of the basin (Rees et al. 2009) and $\mathrm{N}_{2}$ fixation rates are likely to be much higher in the coastal waters just south of our study area due to the proximity of the Gulf Stream where Trichodesmium and other tropical diazotrophs are known to occur (Prufert-Bebout et al. 1993). Estimates of $\mathrm{N}$ inputs from $\mathrm{N}_{2}$ fixation for the entire North Atlantic basin range from 0.09 Tmol $\mathrm{N} \mathrm{yr}^{-1}$ to 8.7 Tmol $\mathrm{N} \mathrm{yr}^{-1}$ (Capone et al. 2005; Mahaffey et al. 2005; Carpenter and Capone 2008). Consequently, it is likely that $\mathrm{N}_{2}$ fixation for the entire North Atlantic basin has been underestimated due to the exclusion of coastal waters.

Although $\mathrm{N}_{2}$ fixation is just a small fraction of the total new $\mathrm{N}$ input to this coastal system, as compared with riverine flow and atmospheric deposition, it may be increasingly significant in future oceanic $\mathrm{N}$ budgets given projections that high $\mathrm{CO}_{2}$ and temperature may favor $\mathrm{N}_{2}$ fixation and growth of colonial and unicellular diazotrophs (Hutchins et al. 2009). In order to better estimate $\mathrm{N}$ inputs via marine planktonic $\mathrm{N}_{2}$ fixation at present and in the future, we require a better understanding of where $\mathrm{N}_{2}$ fixation occurs in the ocean and the physiology of different groups of diazotrophs.

These are the first results reporting planktonic $\mathrm{N}_{2}$ fixation rates and nifH gene abundances from the temperate North American Mid-Atlantic continental shelf ecosystem (between $35^{\circ} \mathrm{N}$ and $45^{\circ} \mathrm{N}$ latitude), a region where $\mathrm{N}_{2}$ fixation was previously thought to be negligible.

Diazotrophs are more abundant on the Mid-Atlantic shelf than anywhere previously measured in the ocean and $\mathrm{N}_{2}$ fixation rates are comparable to or higher than those 
reported for most oceanic systems (Table 8), yet $\mathrm{N}_{2}$ fixation has not been included in coupled physicalbiological models of $\mathrm{N}$ cycling the Mid-Atlantic Bight shelf region (Fennel et al. 2006) and coastal systems have been neglected in global marine $\mathrm{N}_{2}$ fixation budgets in general (Galloway et al. 2004; Codispoti 2006). Findings from this study suggest that temperate coastal systems can have abundant $\mathrm{N}_{2}$ fixers and that marine $\mathrm{N}$ budgets need to consider coastal $\mathrm{N}_{2}$ fixation activity. Further, we need to reexamine the physiological capacities and limitations of diazotrophic organisms that occupy coastal environments.

\section{Acknowledgments}

We thank the captain and crew of the R/V Hugh R. Sharp and the R/V Delaware II for assistance during field sampling. This work was supported by grants from the National Science Foundation (NSF), the Center for Innovative Technology, and the National Oceanic and Atmospheric Administration to MRM; and the National Aeronautics and Space Administration to MRM and AM; and grants from the NSF and Gordon and Betty Moore Foundation to JPZ. We thank the associate editor and two anonymous reviewers for their insightful comments.

\section{References}

Bird, C., J. M. Martinez, A. G. O’Donnell, and M. Wyman. 2005. Spatial distribution and transcriptional activity of an uncultured clade of planktonic diazotrophic $\gamma$-proteobacteria in the Arabian Sea. Appl. Environ. Microbiol. 71: 2079-2085, doi:10.1128/AEM.71.4.2079-2085.2005

Breitbarth, E., A. Oschlies, and J. LaRoche. 2007. Physiological constraints on the global distribution of Trichodesmiumeffect of temperature on diazotrophy. Biogeosciences 4: 53-61, doi:10.5194/bg-4-53-2007

Capone, D. G., AND others. 2005. Nitrogen fixation by Trichodesmium spp.: An important source of new nitrogen to the tropical and subtropical North Atlantic Ocean. Glob. Biogeochem. Cycles 19: GB2024, doi:10.1029/2004GB002331

Carpenter, E. J., and D. G. Capone. 2008. Dinitrogen fixation, p. 141-198. In D. G. Capone, D. A. Bronk, M. R. Mulholland, and E. J. Carpenter [eds.], Nitrogen in the marine environment. Elsevier.

Church, M. J., C. M. Short, B. D. Jenkins, D. M. Karl, and J. P. ZeHR. 2005. Temporal patterns of nitrogenase gene (nifH) expression in the oligotrophic North Pacific Ocean. Appl. Environ. Microbiol. 71: 5362-5370, doi:10.1128/ AEM.71.9.5362-5370.2005

Codispoti, L. A. 2006. An oceanic fixed nitrogen sink exceeding $400 \mathrm{Tg} \mathrm{N} \mathrm{a}{ }^{-1}$ versus the concept of homeostasis in the fixednitrogen inventory. Biogeosciences 3: 1203-1246, doi:10.5194/ bgd-3-1203-2006

Conley, D. J., AND others. 2009. Controlling eutrophication: Nitrogen and phosphorous. Science 323: 1014-1015, doi:10. 1126/science. 1167755

Davis, C. S., AND D. J. McGillicuddy, JR. 2006. Transatlantic abundance of the $\mathrm{N}_{2}$-fixing colonial cyanobacterium Trichodesmium. Science 312: 1517-1520, doi:10.1126/science.1123570

Deutsch, C., J. L. Sarmiento, D. M. Sigman, N. Gruber, and J. P. DunNe. 2007. Spatial coupling of nitrogen inputs and losses in the ocean. Nature 445: 163-167, doi:10.1038/nature05392

Fennel, K., J. Wilkin, J. Levin, J. Moisan, J. O'Reilly, and D. Haidvogel. 2006. Nitrogen cycling in the Middle Atlantic Bight: Results from a three-dimensional model and implications for the North Atlantic nitrogen budget. Global Biogeochem. Cycles 20: GB3007, doi:10.1029/2005GB002456
Foster, R. A., A. Subramaniam, C. Mahaffey, E. J. Carpenter, D. G. Capone, and J. P. Zehr. 2007. Influence of the Amazon River plume on distributions of free-living and symbiotic cyanobacteria in the western tropical North Atlantic Ocean. Limnol. Oceanogr. 52: 517-532, doi:10.4319/lo.2007.52.2.0517

Galloway, J. N., AND Others. 2004. Nitrogen cycles: Past, present, and future. Biogeochemistry 70: 153-226, doi:10.1007/s10533-004-0370-0

Grosse, J., D. Bombar, H. N. Doan, L. N. Nguyen, and M. Voss. 2010. The Mekong River plume fuels nitrogen fixation and determines phytoplankton species distribution in the South China Sea during low- and high-discharge season. Limnol. Oceanogr. 55: 1668-1680, doi:10.4319/lo.2010.55.4.1668

Gruber, N., and J. L. Sarmiento. 1997. Global patterns of marine nitrogen fixation and denitrification. Glob. Biogeochem. Cycles 11: 235-266, doi:10.1029/97GB00077

Holl, C. M., And J. P. Montoya. 2005. Interactions between nitrate uptake and nitrogen fixation in continuous cultures of the marine diazotroph Trichodesmium (cyanobacteria). J. Phycol. 41: 1178-1183, doi:10.1111/j.1529-8817.2005.00146.x

Howarth, R. W., R. Marino, J. Lane, and J. J. Cole. 1988. Nitrogen fixation in freshwater, estuarine, and marine ecosystems. 1. Rates and importance. Limnol. Oceanogr. 33: 669-687, doi:10.4319/lo.1988.33.4_part_2.0669

Hutchins, D. A., M. R. Mulholland, and F.-X. Fu. 2009. Nutrient cycles and marine microbes in a $\mathrm{CO}_{2}$-enriched ocean. Oceanography 22: 88-105, doi:10.5670/oceanog.2009.103

JAHnKe, R. A. 2010. Global synthesis, p. 597-615. In K. K. Liu, L. Atkinson, R. Quinones, and L. Talaue-McManus [eds.], Carbon and nutrient fluxes in continental margins: A global synthesis. Springer-Verlag.

Jenkins, B. D., G. F. Steward, S. M. Short, B. B. Ward, and J. P. ZEHR. 2004. Fingerprinting diazotroph communities in the Chesapeake Bay by using a DNA macroarray. Appl. Environ. Microbiol. 70: 1767-1776, doi:10.1128/AEM.70.3.17671776.2004

Langlois, R. J., D. Hümmer, And J. LaRoche. 2008. Abundances and distributions of the dominant nifH phylotypes in the Northern Atlantic Ocean. Appl. Environ. Microbiol. 74: 1922-1931, doi:10.1128/AEM.01720-07

- J. LARoche, And P. A. RAAB. 2005. Diazotrophic diversity and distribution in the tropical and subtropical Atlantic Ocean. Appl. Environ. Microbiol. 71: 7910-7919, doi:10.1128/AEM.71.12.7910-7919.2005

Ludwig, W., AND OTHERs. 2004. ARB: A software environment for sequence data. Nucleic Acids Res. 32: 1363-1371, doi:10.1093/ nar/gkh293

Mahaffey, C., A. Michaels, and D. G. Capone. 2005. The conundrum of marine nitrogen fixation. American Journal of Science 305: 546-595, doi:10.2475/ajs.305.6-8.546

Mohr, W., T. Grobkopf, D. W. R. Wallace, and J. LaRoche. 2010. Methodological underestimation of oceanic nitrogen fixation rates. PLoS ONE 5: e12583, doi:10.1371/journal. pone. 0012583

Moisander, P. H., R. A. Beinart, M. Voss, and J. P. Zehr. 2008. Diversity and abundance of diazotrophic microorganisms in the South China Sea during intermonsoon. The ISME J. 2: 954-967, doi:10.1038/ismej.2008.51 and doi: 10.1038/ ismej. 2008.84

- AND OTHERS. 2010. Unicellular cyanobacterial distributions broaden the oceanic $\mathrm{N}_{2}$ fixation domain. Science 327: 1512-1514, doi:10.1126/science. 1185468

Montoya, J. P., C. M. Holl, J. P. Zehr, A. Hansen, T. A. Villareal, And D. G. Capone. 2004. High rates of $\mathrm{N}_{2}$ fixation by unicellular diazotrophs in the oligotrophic Pacific Ocean. Nature 430: 1027-1031, doi:10.1038/nature02824 
, M. Voss, P. Kaehler, and D. G. Capone. 1996. A simple, high precision tracer assay for dinitrogen fixation. Appl. Environ. Microbiol. 62: 986-993.

Mulholland, M. R., C. A. Heil, D. A. Bronk, J. M. O’Neil, and P. W. Bernhardt. 2006. Nitrogen fixation and regeneration in the Gulf of Mexico. Limnol. Oceanogr. 51: 1762-1776, doi:10.4319/lo.2006.51.4.1762

- AND M. W. Lomas. 2008. N uptake and assimilation, p. 303-384. In D. G. Capone, D. A. Bronk, M. R. Mulholland, and E. J. Carpenter [eds.], Nitrogen in the marine environment. Elsevier.

—, K. Ohki, and D. G. Capone. 2001. Nutrient controls on nitrogen uptake and metabolism by natural populations and cultures of Trichodesmium (Cyanobacteria). J. Phycol. 37: 1001-1009, doi:10.1046/j.1529-8817.2001.00080.x

Needoba, J. A., R. A. Foster, C. Sakamoto, J. P. Zehr, and K. S. JoHNSON. 2007. Nitrogen fixation by unicellular diazotrophic cyanobacteria in the temperate oligotrophic North Pacific Ocean. Limnol. Oceanogr. 52: 1317-1327, doi:10.4319/1o.2007.52.4.1317

Nixon, S. W., AND OTHERS. 1996. The fate of nitrogen and phosphorus at the land-sea margin of the North Atlantic. Biogeochemistry 35: 141-180, doi:10.1007/BF02179826

Orcutt, K. M., F. Lipschultz, K. Gundersen, R. Arimoto, A. F. Michaels, A. H. Knap, and J. R. Gallon. 2001. A seasonal study of the significance of $\mathrm{N}_{2}$ fixation by Trichodesmium spp. at the Bermuda Atlantic Time-series Study (BATS) site. DeepSea Res. Part II 48: 1583-1608, doi:10.1016/S09670645(00)00157-0

Paerl, H. W. 2008. Nutrient and other environmental controls of harmful cyanobacterial blooms along the freshwater-marine continuum. Advances in Experimental Medicine and Biology. 619: 217-237, doi:10.1007/978-0-387-75865-7_10

Parsons, T. R., Y. Maita, and C. Lalli. 1984. A manual of chemical and biological methods for seawater analysis. Pergamon Press.

Prufert-Bebout, L., H. W. Paerl, and C. Lassen. 1993. Growth, nitrogen fixation, and spectral attenuation in cultivated Trichodesmium species. Appl. Environ. Microbiol. 59: 1367-1375.

Rees, A. P., J. A. Gilbert, and B. A. Kelly-Gerreyn. 2009. Nitrogen fixation in the western English channel (NE Atlantic Ocean). Mar. Ecol. Prog. Ser. 374: 7-12, doi:10.3354/meps07771

Short, S. M., B. D. Jenkins, And J. P. Zehr. 2004. Spatial and temporal distribution of two diazotrophic bacteria in the Chesapeake Bay. Appl. Environ. Microbiol. 70: 2186-2192, doi:10.1128/AEM.70.4.2186-2192.2004
, AND J. P. ZeHr. 2005. Quantitative analysis of nifH genes and transcripts from aquatic environments. Methods Enzymol. 397: 380-394, doi:10.1016/S0076-6879(05)97023-7

, AND - 2007. Nitrogenase gene expression in the Chesapeake Bay Estuary. Environ. Microbiol. 9: 1591-1596, doi:10.1111/j.1462-2920.2007.01258.x

Solarzano, L. 1969. Determination of ammonia in natural waters by the phenohypochlorite method. Limnol. Oceanogr. 14: 16-23, doi:10.4319/1o.1969.14.1.0016

Staal, M., F. J. R. Meysman, and L. J. Stal. 2003. Temperature excludes $\mathrm{N}_{2}$-fixing heterocystous cyanobacteria in the tropical oceans. Nature 425: 504-506, doi:10.1038/nature01999

Tamura, K., J. Dudley, M. Nei, and S. Kumar. 2007. MEGA4: Molecular evolutionary genetics analysis (MEGA) software version 4.0. Mol. Biol. Evol. 24: 1596-1599, doi:10.1093/ molbev/msm092

TripP, H. J., AND OTHERS. 2010. Metabolic streamlining in an open-ocean nitrogen-fixing cyanobacterium. Nature 464: 90-94, doi:10.1038/nature08786

Voss, M., P. Croot, K. Lochte, M. Mills, and I. Peeken. 2004. Patterns of nitrogen fixation along $10^{\circ} \mathrm{N}$ in the tropical Atlantic. Geophys. Res. Lett. 31: L23S09, doi:10.1029/2004GL020127

Welschmeyer, N. A. 1994. Fluorometric analysis of chlorophyll $a$ in the presence of chlorophyll $b$ and phaeopigments. Limnol. Oceanogr. 39: 1985-1992, doi:10.4319/1o.1994.39.8.1985

Zehr, J. P., AND OTHERs. 2008. Globally distributed uncultivated oceanic $\mathrm{N}_{2}$-fixing cyanobacteria lack oxygenic photosystem II. Science 322: 1110-1112, doi:10.1126/science.1165340

, B. D. Jenkins, S. M. Short, and G. F. Steward. 2003. Nitrogenase gene diversity and microbial community structure: A cross-system comparison. Environ. Microbiol. 5: 539-554, doi:10.1046/j.1462-2920.2003.00451.x

- 2 AND H. W. PAERL. 2008. Biological nitrogen fixation in the marine environment, p. 481-525. In D. L. Kirchman [ed.], Microbial ecology of the oceans, 2nd ed. Wiley-Liss. - AND P. J. Turner. 2001. Nitrogen fixation: Nitrogenase genes and gene expression, p. 271-286. In J. H. Paul [ed.], Methods in microbiology. Academic Press.

Associate editor: Mikhail V. Zubkov

Received: 29 July 2011

Accepted: 12 March 2012 Amended: 27 February 2012 